Illinois State University

ISU ReD: Research and eData

Theses and Dissertations

$7-22-2020$

\title{
The Role Of Microfinance Workers In Financialization: Negotiating The Meaning Of Development In China
}

Xue Ma

Illinois State University, maxuedec@gmail.com

Follow this and additional works at: https://ir.library.illinoisstate.edu/etd

Part of the Quantitative, Qualitative, Comparative, and Historical Methodologies Commons

\section{Recommended Citation}

Ma, Xue, "The Role Of Microfinance Workers In Financialization: Negotiating The Meaning Of Development In China" (2020). Theses and Dissertations. 1298.

https://ir.library.illinoisstate.edu/etd/1298

This Thesis is brought to you for free and open access by ISU ReD: Research and eData. It has been accepted for inclusion in Theses and Dissertations by an authorized administrator of ISU ReD: Research and eData. For more information, please contact ISUReD@ilstu.edu. 


\section{THE ROLE OF MICROFINANCE WORKERS IN FINANCIALIZATION: NEGOTIATING THE MEANING OF DEVELOPMENT IN CHINA}

\section{Xue Ma}

\section{Pages}

Microfinance is an attempt to alleviate poverty through offering collateral-free small loans to poor borrowers, especially women in developing countries or rural areas. Though it is indeed an actual economic activity, usually engaged in through some type of bank, there is much that is informal and context-bound in these transactions, making microfinance a kind of "social business." While the impact of microfinance on women borrowers has been discussed many times, only a few studies have looked at the significance of the other members of the interaction: the microfinance workers, who are instrumental intermediaries between the women-borrowers and the microfinance institutions who attempt to market their products. The role of the microfinance worker-intermediaries is critical. Studying the role of the microfinance worker not only helps us understand how microfinance is actually practiced, but also reveals how the complexities of micro-financialization entails not purely economic and calculative activities, but also complex social interactions and meaning-making.

This research studies workers in the microfinance industry in rural China by examining their everyday interaction with the borrowers. I show that the success of any given microfinance interaction has much to do with the competence, knowledge, and sensitivity of the individual microfinance worker. And their skill set depends on a number of factors, including their own understanding about the job and what the actual aim of microfinance is. The different 
participants in these interactions can sometimes have different agendas, or different ways of communicating them. Sometimes due to specific contingencies in specific contexts, a particular interaction may or may not succeed. Thus, sometimes the development-mission of microfinance can 'drift' away or become forgotten. Much depends, then, on the "relational" talents of the microfinance worker. Indeed, the relational work from these intermediary workers directly shapes the micro-financialization process.

By examining the workers' motivations, their "tenuous positions" (Kar 2013) as intermediaries between borrowers and lenders, and how they attempt to balance providing services to their potential borrowers while also maintaining their fiduciary responsibilities to their lending institutions, we can more fully understand the complexities of the microfinance process in daily life. As microfinance has often been touted as a pragmatic solution to possibly alleviating much poverty world-wide, this study has both practical as well as theoretical import.

KEYWORDS: Microfinance; China; workers 
THE ROLE OF MICROFINANCE WORKERS IN FINANCIALIZATION: NEGOTIATING THE MEANING OF DEVELOPMENT IN CHINA

XUE MA

\author{
A Thesis Submitted in Partial \\ Fulfillment of the Requirements \\ for the Degree of \\ MASTER OF SCIENCE \\ Department of Sociology and Anthropology \\ ILLINOIS STATE UNIVERSITY
}

2020 
Copyright 2020 Xue Ma 
THE ROLE OF MICROFINANCE WORKERS IN FINANCIALIZATION: NEGOTIATING THE MEANING OF DEVELOPMENT IN CHINA

XUE MA

COMMITTEE MEMBERS:

James Stanlaw, Chair

Aaron Z. Pitluck, Co-chair 


\section{ACKNOWLEDGMENTS}

I would like to extend my sincere gratitude to my mentors in this journey at ISU: Prof. James Stanlaw and Prof. Aaron Pitluck. Thanks for the countless meetings and conversations over the past two years, especially in these recent months when we had to rely on remote communication strategies. Thanks for the detailed, constructive and always-encouraging feedback in this thesis writing process. And lastly, thanks for being inspirational guides on this journey. I could not have finished this thesis without the encouragement from both of you, who have absolutely influenced my world-view, my thinking, and my aspirations for continuing this journey in anthropology.

X. M. 


\section{CONTENTS}

Page

ACKNOWLEDGMENTS

i

CONTENTS

ii

FIGURES

CHAPTER I: INTRODUTION

Why Microfinance? 1

$\begin{array}{ll}\text { Research Questions } & 4\end{array}$

$\begin{array}{ll}\text { Methodology } & 6\end{array}$

Interning at Better Life $\quad 6$

About the Field Site $\quad 8$

About the County 9

$\begin{array}{ll}\text { Daily Routine at the MFI } & 10\end{array}$

$\begin{array}{ll}\text { Typical Daily Schedule } & 10\end{array}$

Typical Sales Pitch Scenario $\quad 11$

The Procedure of Loan Application and Loan Collection 13

CHAPTER II: LITERATURE REVIEW OF MICROFINANCE 15

The Controversial Discourse of Development in Microfinance 16

$\begin{array}{ll}\text { Microfinance and Social Capital among Borrowers } & 17\end{array}$

Borrower-Lender Relations in Microfinance $\quad 20$

Financial Inclusion Agenda and Credit Market Expansion in China 21

Financial Inclusion and Poverty Alleviation as Political Task $\quad 21$ 
History of Microfinance in China $\quad 24$

Expanding the Debt Market in China $\quad 25$

CHAPTER III: REDEFINED DEVELOPMENT AND WORKERS' TENUOUS POSITION 29

Aspiration While Working at a Microfinance Institution 30

A Clean Space Compared to the Dirty Finance World 32

A Humane Job to Change the World 33

Only Another Job So I Can Eat: No Mission -Spirit Needed 35

The "Ethically Tenuous Position" of Workers in Microfinance Institutions 36

Avoid the Image of "Just Another Money-lender” 36

Letting the Members Down after Loans are Rejected by CEB $\quad 42$

Contemplating and Redefining Development 45

$\begin{array}{ll}\text { Conclusion } & 46\end{array}$

CHAPTER IV: RELATIONALITY IN THE WORKER AND BORROWER

RELATIONSHIP 49

Imagined Relations in Microfinance $\quad 50$

Relational Work Theory $\quad 53$

Relational Work in Microfinance $\quad 55$

Invoking Borrowers’ Empathy

Expecting Reciprocity of Respect and Recognition $\quad 56$

More Sincere, Less Superficial

What Kind of Financial Product is This? $\quad 60$

Defending the Distinctive Advantages of this Product: Weekly Repayment 60

Interest Rate Confusion $\quad 61$ 
$\begin{array}{ll}\text { Group Formation } & 63\end{array}$

$\begin{array}{ll}\text { Conclusion } & 64\end{array}$

CHAPTER V: CONCLUSION

Understanding Motivation and Positions of MFI Workers 67

$\begin{array}{ll}\text { A Relational Analysis of Microfinance } & 68\end{array}$

$\begin{array}{ll}\text { Conclusion } & 70\end{array}$

$\begin{array}{ll}\text { Future Research } & 74\end{array}$

$\begin{array}{ll}\text { REFERENCES } & 75\end{array}$ 


\section{FIGURES}

Figure Page

1. Practice Guideline for Better Life Microfinance 50

2. Interest Table from the Better Life Brochure 62 


\section{CHAPTER I: INTRODUTION}

\section{Why Microfinance?}

Microfinance aims to create a banking system for the poor based on trust, participation and creativity, instead of the traditional banking requirements such as collateral and guarantor. Microfinance has been practiced many countries in the world including USA, Mexico, Turkey... with a repayment rate as high as 99\%. It has been proved as a sustainable model to alleviate poverty worldwide.

\section{— Better Life Microfinance Institution, Introduction}

Better Life (BL) is the pseudonym for a microfinance institution (from hear on, abbreviated as "MFI") that I was studying in China. It is a non-governmental organization, defined by itself as a "social business". The quote above, from Better Life's official website, delivers the key message about microfinance to stakeholders such as donors, collaboration partners, borrowers, and possibly the media. It also gives information to potential employees before they apply for a job. The key assumption about why microfinance could work for the poor is that the poor are as trustworthy people who already have collateral and guarantees from the bank. It is assumed that as long as the poor are given access to some small capital, they can make a good living (through entrepreneurship, or "creativity" mentioned above), and gradually become lifted out of poverty. Meanwhile, the microfinance mechanism emphasizes "participation", which is microfinance's unique group-lending model. Participation aims to bring women borrowers together, during every repayment meeting. Many microfinance programs have the group members being responsible for each other's loans, but it is not the case for every MFI. The MFI I studied has explicitly said to its borrowers that there is no financial liability towards other 
members if someone fails to repay. Gender is a key component in MFI Better Life as it targets women borrowers only.

As mentioned previously, the essence of microfinance is its banking system. Traditional banking in the old way of doing business was not especially concerned about social responsibility. But in the microfinance model, banking works towards economic development as its mission. As a banking system, microfinance attempts to encourage sustainability. Advocates of microfinance believe the system is replicable worldwide, including in developed countries such as the United States.

Currently, the system of microfinance has gained enough world-wide attention for its pioneering model of empowering the poor by giving loans to them and potentially alleviating poverty. Grameen Bank is the name of the MFI in Bangladesh that initiated the one of the first microfinance programs in 1970s and 1980s (Grameen Bank Official website, Nobel Peace Prize website). Ever since then, microfinance has gradually gained fame all over the world, especially after the founder of Grameen Bank, Muhammad Yunus, was awarded the Nobel Peace Prize in 2006. Microfinance, however, is in fact an umbrella term for a number of activities providing bank services to people previously regarded as un-bankable. These services include savings, insurance plans, fund transfers, and the most widely practiced and studied feature: micro-loans or micro-credits. When referring to microfinance in this thesis, I will mostly be referring to the specific micro-loan or micro-credit "product" targeting poor women, with a group-lending format, though occasionally I will use it to refer to the microfinance industry in general.

Group lending to women borrowers is the distinctive mechanism of microfinance. The idea of microfinance is to make borrowers successful entrepreneurs with the microloan capital they borrowed, and lift borrowers out of poverty through these small businesses they are able to 
start. Microfinance also emphasizes making friends and social connections, leading to a better life for the borrowers' family and the community in general. Microfinance had been increasing in popularity since 1990s — after beginning at first in developing countries in 1970s (Collins et al. 2009) - until a downturn in 2000s (Hsu 2017:5). The microfinance climate remains cool today (Hsu 2017: 5) despite some new programs being established now and then.

In China, microfinance experienced various different stages of development (Du 2004). In early years (1994-1996), non-governmental organizations which received funding from international aid agencies and organizations, along government-NGO-collaboration, established microfinance institutions in rural China, often modeled after the famous Grameen Bank. The second stage (1996-2000), in addition to the NGOs working on microfinance, the Chinese government also began to put into more funding into microfinance, and supported financial institutions like the Agricultural Bank of China to implement the microfinance model. The third stage is when Rural Credit Unions (or Rural Credit Co-ops) began to practice microfinance nationwide since 2000 (Du 2004). However, the MFI which I studied for this research is a unique example that doesn't strictly fit into any of these three categories. This MFI started as an experiment by the president of Better Life, who was a former journalist and had worked on rural problems for many years.

Today, microfinance in China is situated in a new market environment, where debt expansion in recent decades now makes loans ubiquitous. For example, the e-commerce giant Alipay has been operating its own credit product since 2015, and has gained rapid growth within the last five years because it is one of the go-to credit products many people use today for small to medium-sized loans. In the meantime, the growth of small loan companies has been over $40 \%$ in 2019, and personal consumption loan growth is also around 40\% (Credit Market Report 2019). 
Debt expansion due to technology changes have not only brought people easily-accessible loans, it has also presented challenges to MFIs who need to differentiate themselves from these other products by stressing the development mechanism they offer.

\section{Research Questions}

It is in this ever-financialized environment today in China, that I begin to ask what could microfinance offer for poverty alleviation today when credit—and debt—is accessible now to so many people? To date, much research on microfinance in various social and cultural contexts has looked at the impact of microfinance on borrowers - especially in social capital formation - in order to understand how social relationships and effective microfinance capital might empower women (or not) (Rankin 2002, Elyachar 2005, Beck and Radhakrishnan 2017, Hsu 2017, Young 2010, Schuster 2015, Kar 2018). The situation in China, especially with the new more-open credit market which is easier to access for many people, led me to ask not just "Does microfinance help borrowers?" but also "What is unique about microfinance that is different from other loans available?" This idea of microfinance being financialization process with a development mission meat that the professional staff members at microfinance institutions hold great responsibilities to carry out these tasks. Thus, I decided to look the work of MFI staff members, and ask how they see the world of microfinance, what it means to them, and how effectively they feel they can carry out their mission.

This research attempts to understand the roles of MFI workers in financialization, through their narratives and practices in their everyday work. This involves interacting with women borrowers constantly. Specifically, this thesis examines the practices of microfinance by looking at the workers in MFIs who are the ones actually doing microfinance every day. I do so by looking at the narratives the MFI workers themselves use to talk about, the think about, 
microfinance. The program I studied for is a newly implemented MFI in a semi-rural town in China, with a big national bank as the key collaborator when offering funding and loan approval. By looking at the everyday routines of these MFI workers, I seek to understand how the MFI workers reconcile the financial features of the business side of microfinance with its development side. Specifically, I will address two key questions in this thesis:

1. How is development interpreted by MFI workers and what significance does this have for their practice of microfinance?

2. What roles do MFI workers play in micro-financialization? What meaningful relationships occur between borrowers and MFI workers in the financialization, and what kind of "relational work" do they make in loan-related decision-making process?

The structure of this thesis is as follows: In the next section, I will explain the methodology I used for conducting the fieldwork. In Chapter 2, I will review the relevant studies that situate my research about workers of microfinance in China today into a specific context. In Chapter 3, I will present a picture of the MFI workers in the field by going through their daily work routine. I look at why they work in microfinance, the challenges they face in their work environment today, and ask what they feel the meaning of their work is (particularly in relation to development). In Chapter 4, I will present some narratives about interactions between workers and borrowers that enrich the relations in microfinance, and in financialization in general. In Chapter 5, I will conclude by arguing that the meaning of development in microfinance is constantly negotiated and renegotiated by MFI workers in their daily routine. And these meanings are also affected by relations between the borrower and worker. Such relations go 
beyond the lender-borrower relationship in practice, and make microfinance a unique example to how social relations and personal dynamics affect the financialization process.

\section{Methodology}

\section{Interning at Better Life}

This study is based on my three-month field experiences as an intern at Better Life, a microfinance institution in China. As a relative new-comer, the MFI allowed me to shadow the workers, watch the routine of work, participate in training sessions, and attend weekly meetings. I worked along with the MFI workers at Yunling branch of the Better Life MFI (a pseudonymous location and firm). Specifically, I did archival study, participant-observation, and had informal conversations in the field.

Archival study was the primary method used throughout this study to understand the history of the field site, as well as the operation of the MFI. The MFI program promotion material, sample copies of loan application forms, working guidelines, contracts with the China Enterprise Bank, and local loan usage research reports were provided from the MFI.

As an intern, I also used participant-observation as a field method to collect data about daily working routines, borrower-worker interactions in public space, and reflections from workers about their work. I followed MFI workers as they walked door by door visiting potential borrowers, introducing this loan product. I also attended one official meeting with MFI workers on the topic of service improvement, which was organized by the China Enterprise Bank and top MFI managers. After my fieldwork, I returned to the site and attended one workshop training session on a weekend. Sometimes we traveled by taking local buses to nearby townships to do client research about potential markets. Though I was a participant in many of the daily work routines, I did not take the lead in any major duties such as recruiting members, training 
members, approving loan applications, or repayment collections. If I was introduced to clients, sometimes the workers would mention that I was an intern, or also that I was a student doing research.

I was living with MFI workers in a rented three-bedroom dorm, sharing one bedroom with another MFI worker. In daily life, this meant a shared lifestyle of grocery shopping, cooking and eating together. There were many insightful and inspirational conversations happening during shared dinners with the MFI workers.

I conducted informal conversations with MFI workers during the gaps of daily work routines. The informal interviews were sometimes conducted in a very segmented way though I tried to capture the main point of an immediate response. In informal conversations I often asked questions on the following topics:

1) About the workers' aspiration: How did you find this job? What is your dream career or work?

2) About the workers' interpretation and perception of this job: How do you talk to your family or friends about your job? What do you think is the most important character quality or ability in this job? What is most challenging about this job? What progress or influences do you see this job giving you?

3) About workers' views on this microfinance product: Why do you think clients choose this product? If it was not a requirement from China Enterprise Bank (CEB), would the client base be different?

4) About worker and borrower interaction: What kind of relationship do you think should borrower and an microfinance worker have? Do you have any events or stories between you and member that you want to share? 
I choose to protect the privacy of the specific MFI, members/clients/women-borrowers, and employees/workers/center managers by using pseudonyms instead of real names and locations. Also, the observations here are not intended to be reflections about any specific MFI or microfinance project, its performance, or it employees. The purpose of this thesis is to understand microfinance in general, as well as the effects of financialization on social relations (and social relations on financialization).

\section{About the Field Site}

The field site was unique in several ways. First, it is a very young branch. This branch where I did an internship was in its second month of operation when I arrived. There are three other branches in the same greater area of this province in West Central China. The earliest established branch among the entire four branches in this greater area started out just four months earlier than the branch I was staying. Overall, these branches are very new to the area, but the central staff members, such as the branch managers and experienced central managers (CMs), are all from an earlier microfinance project of this MFI, at another location in China. Second, during the time of my stay as an intern, the staff members at this branch were all female. This is not typical in MFIs; usually there is a mix of genders in the branch. This all-female branch turns out to be a bit special and meaningful because of later observations on how women borrowers interact with some of the female workers. Third, this branch is located at a nationally recognized underdeveloped area (guo jia ji pin kun xian 国家级贫困县). There are government affiliates designated for poverty alleviation tasks in this area. The most recent update shows, at the time of this writing, that this county has just been removed from this list.

Although these idiosyncratic characteristics of this field do not make it representative, this specific branch had many common features typical of MFIs: a poverty rare similar to other 
places where the same microfinance model was implemented (such as with the Grameen Bank), and a set of meaningful social relations daily work routines typical of MFIs.

\begin{abstract}
About the County
Yunling, the pseudonym of this county where this branch is located, is a county with about 300,000 people. This is about the average population size of a county in China. Rural residents occupy about 57\% in Yunling. The primary livelihood of the rural residents is agriculture, and many people have become migrant workers in the past decades, under the general economic shifts in China for the past thirty to forty years. Migrant workers have long been an economic and labor market change in China, ever since 1980s. The women borrowers in Yunling are from both rural and urban backgrounds. Many of them have been migrant workers before.
\end{abstract}

The geographical features of Yunling contributes partly to the slow economic development here; but on the plus side, it has a relatively unpolluted environment. People from the outside of this area would often say, "This place has less contact with the outside". This stereotype says something about the general impression people have about Yunling. The entire county is surrounded by mountains and rivers, making transportation to Yunling very difficult prior to the highway being constructed. More than 100 years ago, it took 9 days to complete a trip from Yunling to the nearest metropolitan city for selling goods, nowadays it takes 3.5 hours by car and 4 hours by train. Overall, Yunling is on the list of slow economic development areas in the province and its location has a lot to do with its slow economic development.

According to the latest available report on economy and development in Yunling, the average disposable income for Yunling residents is $¥ 14335$ RMB per capita ( $\approx \$ 2000$ USD). Urban per capita disposable income is $¥ 24380$ RMB ( $\approx \$ 3400$ USD) and the rural per capita 
disposable income is $9160 \mathrm{RMB}(\approx \$ 1300 \mathrm{USD})$. The national average disposable income per capita in China at the same year (2018) was $¥ 28228$ RMB $(\approx 3985$ USD) while the urban statistics for this number in national level is $¥ 36413$ and the rural is $¥ 13066$, indicating that the disposable income and general economic development in Yunling is significantly lower than national average.

\section{Daily Routine at the MFI}

\section{Typical Daily Schedule}

The center managers work five days a week, from $9 \mathrm{am}$ to $12 \mathrm{pm}$, then $2 \mathrm{pm}$ to $6 \mathrm{pm}$. Occasionally, group training that normally needs to take place for 5 consecutive days will occupy the weekends for center managers. At such case, there will be paid days off for the break time occupied by group training.

The dorm is not far from the branch office, just about 5-7mins walk. Everyone arrives at the office before 9, about the same time because the staff often go together from the dorm. One worker will get breakfast for everyone and the first 20 mins is usually breakfast time, while people discuss some working problems. Around 9:30 or 10am, center managers go out to recruit potential members. They often go in pairs because it's safer. Therefore, the work is not the typical office job that many banking or financial professionals have. This job involves a significant amount of walking, or biking/motorcycling than at some other branches. CMs walk for about two hours in the morning and three hours in the afternoon, while introducing the program to potential borrowers by visiting their shops one by one. At this town, small shops are not just on the streets, but also in the alleys, or inside some apartment buildings. By the time I arrived at the field site (one month after the establishment of this branch), the CMs have already gone to almost every small shop in this county. 
While walking on the streets, CMs may encounter the existing members or clients of this branch. Often times, they greet the member by calling the respect name: "Hu a yi (Auntie Hu)!" Then they would have a small chat with the member on the street- the typical exchange of greetings among friends or acquaintances in China.

By 5:00pm, CMs will be back at the office for meetings. Often, there is a weekly or daily meeting among the center managers and branch manager, discussing weekly/daily progress, updates, problems, or the work plan for next day or week. The most frequently discussed topic at this stage is still about recruiting new member-clients. Sometimes, the meeting is for training about certain issues: How to address the problems of members who have difficulty repaying? What topics should we discuss at center meetings each week with members? What are the application details from the CEB loans and how carefully should CMs screen members before sending their documents to CEB for loan approval?

Occasionally, there is a Member's Day event. Such events usually gather members together for games or gifts, and offers space for casual chatting. Most important, this is part of the social aspect of that is emphasized at Better Life, to develop social capital and support for its members.

\section{Typical Sales Pitch Scenario}

A significant amount of work at the beginning stage of this branch is all about recruiting members. Here is the typical scenario. Two CMs walk into a small restaurant that is not busy (because they are required by the company not to interrupt the usual business) and start a conversation like: "Excuse us, we are from the CEB and we have a program called the 'Women's Entrepreneurial Loan' that we would like to talk to you about, seeing as you own a small business. This is a collateral-and guarantor-free loan that we aim to give to women who are 
18-64 years old. It is intended to help your business. For a loan 10,000 rmb, the interest for one year is $316 \mathrm{rmb} . . . "$ CMs usually could sense the interest level of the business owner and decide how to proceed or stop at the right time.

Usually people who are interested in the loan would note that the interest rate appeared attractive and ask how they could apply for the loan. After explaining the requirements ("Your ID card, residential registration card, and your business license, and if you are married, your marriage certificate is also required, but a copy is okay"), CMs would continue to explain the distinctive parts of this loan product, which differentiates itself from loans from regular banks. But they also explain the social purpose behind it: "Our loan product is a bit special. We require weekly repayments, but we would come to you. There is no need for you to go to the bank. And also, you would need to form a five-person group. But no worries there, as there is no obligation among the five borrowers. We just hope to get five women together and let you have a place to share your business difficulties, or family concerns, etc. You know, as they say, 'Getting closer, we will all get warm' ... As women we all share similar concerns like our kids' education, women's health issues, ... and this group is for this purpose. We will also have a five-day training at first, only about 30mins each day, before we help you apply for the loan.” Here, many people who are already hesitant about the loan product will find the weekly repayment or the five-day training burdensome. "You see how busy I am running this restaurant. It's hard to go to the training meetings or do a weekly repayment. Why is this different from other bank loans, which I just need to repay monthly?" CMs would continue to explain why the five-day training is necessary and why weekly repayments is good for them: "The training is mainly to explain our loan products in detail and it only takes half an hour each day ... And our program has found that weekly repayment is most helpful and easiest for our members who are small business owners. 
Because your business has daily cash flow, you just need to take out some of it each week to repay, so you will find this is much less pressure than a one-time repayment or monthly repayment. After 50 weeks, it's all paid and clear."

\section{The Procedure of Loan Application and Loan Collection}

After the potential client shows interest in borrowing, a CM would arrange five to seven clients from nearby areas to start a group training, as the official start of the loan application. The group training takes five consecutive days in a row, introducing what is microfinance, the history and mission of Better Life, and the details about loan payment—such as the repayment amount and repayment schedule, as well as selecting leader of the group, and explaining the rule agreements in the group. Each time, the training takes place at one client's home or shop. The purpose of this training is to let members familiarize themselves with the product and also get to know each other. By the end of the training, CMs would also have finished the application forms for each member, after visiting each member's home or shop several times and asking questions and filling out forms.

Right after the end of training, CMs would make an appointment with a local CEB loan officer who is in charge of this program at the CEB branch to do the loan application interview. The borrower will have to be there in person, opening CEB bank account, signing and submitting documents. All of this is under the CMs' guidance. Once the paperwork is submitted to the higher level at the CEB's loan application center for review, the CMs and the borrower will just have to wait for the results. If approved, there will be credit available in the borrower's bank account at the CEB immediately, and they must promise making repayments every week at the weekly center meetings. If the loan application center at the CEB rejects the loan, they will explain reasons of why. 
After getting a loan, a borrower is supposed to use this capital for her business and generate more income for her family. She will repay in small installments each week at the center meeting held at one borrower's home. During the center meeting, CMs will host the meeting, and expect attendance of all members in this group. The meeting is started with roll call to check the attendance of the members. The group leader who was elected by the members will call each member's name to check attendance. Then there is the ritual of reciting or reading the "agreement contract" which include verbal promises such as "I will work diligently, and have team-spirit and discipline. We will find a safe and comfortable place for the center meeting. We will have our children get a good education, and make money for their tuition ..." In practice, especially at the beginning stage, CMs only ask the members to recite or read the first phrase instead the entire "agreement contract." Then the CM who is responsible for this group will introduce some topics for discussion, such as how to recognize fake currency (which the CMs believe is a useful skill for small business owners like their clients), and how to overcome various difficulties in business and in life. In order to have every member feeling engaged, the $\mathrm{CM}$ tries to encourage full participation from the members by asking everyone's opinion or experiences to share. After some discussion, the CMs will collect the repayments, in cash. (Most of the time, as is the requirement from the Better Life guidebook, CMs need to carry the cash back to the office and record the daily cash balances, etc., in the accounting books.) The entire meeting ends with the same ritual as its start, by reciting or reading the "agreement contract". 


\section{CHAPTER II: LITERATURE REVIEW OF MICROFINANCE}

In this chapter, I will review some of the scholarly literature on microfinance, with an emphasis on four aspects that are closely related to this research: 1) What is the general discourse regarding development in microfinance? 2) What are the dynamics of the social relations involved in microfinance? 3) What has been studied to date about borrower and lender relationships in microfinance? 4) What is the background on microfinance in China and what is the credit environment in China like today? Each of these is an important aspect for understanding what microfinance is trying to achieve, and what microfinance has actually achieved.

In the first section of this literature review, I look at the developmental discourse of microfinance. By contrasting the different views of microfinance advocates and critics, we become force to question what is really meant by "development." The answer to this question is still unclear, but the discussions about microfinance and development show us what policy designers have in mind about microfinance's potential, and what economic framework critical scholars use regarding this discourse. A case can be made that microfinance is not simply a tool to help the poor, but is an extension of a neoliberal economic ideology which reduces the responsibility and accountability of - as well as the risk to - the state. In the second section, I examine studies related to social relations in microfinance. This section looks at the social interactions among borrowers, and borrowers and guarantors (in some microfinance models). These social subtleties reveal the impact of microfinance on borrowers' social lives, especially when examined in a specific cultural context. Microfinance fails in some programs because it didn't take the local social norms into account. In third next section, I review the few studies that talk about borrower and lender relations. These relations actually constitute a significant part of 
microfinance's practice, but it hasn't been discussed fully in literature so far. The last section introduces the background of microfinance in China today. Specifically, I will talk about the institutional environment where "Financial Inclusion" is a national agenda and strategy, and "Poverty Alleviation" is a political task. I then will discuss the economic environment where credit platforms have been made accessible in daily life.

\section{The Controversial Discourse of Development in Microfinance}

Microfinance reached its first peak when Grameen Bank founder- the economist and banker, Muhammad Yunus — was awarded the Nobel Peace Prize in 2006. The significance of this honor is the most popular claim touted by microfinance promoters. Since its beginnings, microfinance has been closely associated with social development as its ultimate mission and purpose.

Studies across different disciplines have paid attention to the development dimension in microfinance. This widely-debated area in microfinance can be traced back to 1980s, when Yunus first established Grameen Bank. The well-circulated story of " 27 dollars and 42 women in Bangladesh's Jobra"1 often repeated by most people in the microfinance industry. The narrative of the story is that the poor are actually good credit risks, under the right conditions, and will become less poor after they make money using the capital they have borrowed. This is how most microfinance designers or leaders believe economic development will occur.

The first examination of microfinance's history on development discourse was made by Young (2010). He focused on the discourse in microfinance as the empowerment of women who were portrayed as a "marginalized population fighting for a more inclusive welfare state," and fighting poverty in the early neoliberal era of (Young 2010: 207). Microfinance exemplifies and

\footnotetext{
${ }^{1}$ See Yunus 2003: Banker to the Poor.
} 
justifies the consequences of scaling back public sector programs. "As microfinance has become increasingly 'mainstreamed' it has molded the logics of moral hazard around an idealized 'moral woman,' one whose nurturing instincts and entrepreneurial potential can be cultivated through microfinance programs, enabling families, communities, and even nations to be lifted out of poverty." (Young 2010: 219)

Many scholars echo Young's argument regarding the neoliberal ideologies governing microfinance: individual responsibility, entrepreneurship, and self-discipline (e.g., Karim 2011; Rankin 2001, 2002; Roy 2010). Another example about entrepreneurship helps explain why expectations become pressure. Borrowers are expected to be a "good entrepreneur" and they are assumed to always behave in the best way to make repayment to the best of her ability. Yet, not everyone is born to be an entrepreneur and putting such expectation on borrowers, especially on women, can sometime just create extra pressure on them (Karim 2011).

The primary idea microfinance is based on this neoliberal perspective that actuallymaybe even intentionally - leaves out the public welfare function of the state. Calculative logics are being perpetuated in women borrowers' lives (Karim 2011): they must have the selfdiscipline to be a good woman, one who will be honored by taking on additional tasks (Rankin 2002). In essence, poor people living in the bottom become unwitting subjects of the global market — with few skills or capital to do so adequately. Microfinance, then — for all its claims to the contrary —is actually an example of hegemonic capitalist market ideology (Roy 2010).

\section{Microfinance and Social Capital among Borrowers}

The voices promoting microfinance recognize the potential of social capital in microfinance, oftentimes presumably positive social capital. Social capital, as commonly defined, refers to the resources and information one can access in a social of community 
network. It is widely believed that social capital brings the poor more information, more resources, more social solidarity (Portes 1998).

Since the invention of microfinance for poverty alleviation in 1970s, mainstream scholarly literature on microfinance has generally supported the claims that is works. That is, much research in economics offers detailed explanations as to why a group-lending model would work (Yunus 1976; Stiglitz 1990). Specifically, as a mechanism for risk management, it is believed that individuals are incentivized to repay under peer pressure from the members of a group (Andrew \& Burman 1996).

However, the effectiveness of microfinance on development is questioned by some scholars when they look closely into the social relations network in the practice of microfinance. When the subtilties of social relations are taken into account, there appears to be a dilemma in microfinance. Anthropologist Lamia Karim (2011) for instance, uses fieldwork conducted in Bangladesh on microfinance to illustrate the point that microfinance institutions and NGOs manipulate existing kin and social relations to create wealth for the lending-institutions. Borrower's behavior is regulated and shaped by the norms created by the microfinance institutions, and the borrowers are analyzed as entrepreneurial subjects only. Karim argues that such views from the microfinance institutions ignore the parallel social world where the borrowers live, and other social forces also influencing the behavior of borrowers (2011). This is an example of how microfinance institutions utilize social relationships to realize the corporate goal as but the social cost to the borrower.

A similar claim is made by Kar (2017) who studies another type of microfinanceguarantor-based individual lending. For example, poor women in urban India can only access microfinance with the help of a male guarantor who has a kinship relationship with the borrower. 
Kar argues that relationships matters in the guarantor programs and this shows that the requirement of a male guarantor for female borrower when accessing the loan is an illustration of the microfinance institution speculating on a specific type of social relationship, kinship, to its own advantage. Both borrowers and lenders are encountering the utilization of kinship in microfinance, either consciously or involuntarily. Women in urban India struggle to access the loan when the presumed kinship tie to the borrower is broken or disconnected. The reliability on kinship puts extra pressure on women while this is exactly what the microfinance institutions are speculating on to manage the balance of risk and profit (Kar 2017).

In the same article, Kar explains that social relations are transformed when borrowers approach the guarantor in such microfinance models (2017). A mother who cannot have her son as an effective guarantor needs to approach her daughter husband to obtain a loan. But borrowing using her daughter's husband as a guarantor complicates the existing kinship network. And a fictive kin who acts to fulfill the institutional need of guarantor but who is actually only a friend, presents even more subtle and complex social relationships than indicated on the paper application forms. Other "borrower and guarantor" stories further illustrate the additional social risks forced on women even though the microfinance mechanism is claimed to bring social empowerment for women (Kar 2017).

Hsu's research about microfinance in rural China helps explain how responsibilities can actually be coercion. Her research shows that sanctioning or monitoring responsibility could be hard for the villagers due to cultural reasons (Hsu 2016). To the villagers, cultivating relations matter more than anything else, and asking someone to repay a loan is simply hard to even start a conversation about (Hsu 2016). By situating the borrowers and lenders within these cultural norms, it become clear that microfinance doesn't always work as its advocates envision. 
Microfinance advocates have long been arguing that that microfinance is a solution to poverty alleviation; and the mechanisms of microfinance could work even well in many developing countries. Seeing microfinance as a one size fits all model, such promoters ignored the subtleties of communities, especially if there are social collateral systems already in place (such as the cases in rural China mentioned above (Hsu 2016).

\section{Borrower-Lender Relations in Microfinance}

Most literature about social relations in microfinance focus on social capital formation among borrowers - which, after all, is the intended goal of microfinance and the supporting theory behind its operation. Only a small portion of the microfinance literature focuses on the social relations between lender and borrower.

"Lender" is a self-explanatory, yet quite complicated, word because the identity of a lender is not a single individual or entity. This identity could be traced through the line of credit. From the credit recipient's perspective, the microfinance organization or MFI staff members seem to be the visible "lender" in their eyes; from the credit issuing perspective, the funding agency/loan capital resource (such as banks or credit companies) seem to be the "real" lender. No matter how we define lender, the focus of research on microfinance should also include lenders. Several studies incorporate lenders' role in their study of microfinance.

The first study that looks at the role of MFI workers is Kar's 2013 study of credit officers in an Indian microfinance program. The credit officers are called "proxy-creditors" while their own position and role in the local context is also marginal. This study shows the ethical concerns of MFI workers when facing dilemmas of doing their jobs professionally (as quasi-bankers) vs. their understanding and empathizing with the borrowers' difficulties. At the heart of this 
dilemma is "the unresolved tension of capital expansion and ethical concerns," as Kar puts it (2013: 480).

This tension, and the attempt to reconcile it, is often mentioned when looking at the work of MFI workers. In studying the practices of indigenous community members negotiating the terms and payment schedule with MFI workers, Schuster pointed out that "Reconciliation through lending keeps borrower and creditor on intimate terms, which serves as a valuable counterpoint to transaction-based audit processes that seek to fully characterize (and terminate) an economic or social relationship. Instead, the hard social work of reconciliation as an ongoing obligation disrupts accounting practices that seek to zero-out obligation.” (Schuster 2010: 62)

There are also positive examples of significant and sensitive roles played by MFI workers. In a study of a microfinance program in northern India, Goodman found that the local borrowers altered microfinance programs in the NGO to make it fit with their existing borrowing practices and livelihood strategies. She concludes that "to ensure that development programs can be made relevant to people's lives and cultural values, development practitioners must relinquish control over the minutiae of development and allow local-level workers to negotiate the details of projects with participants." (Goodman 2016: 362)

\section{Financial Inclusion Agenda and Credit Market Expansion in China}

\section{Financial Inclusion and Poverty Alleviation as Political Task}

At the time of this writing, microfinance has been operating in China for more than 25 years (Du 2004). Ever since its first experiment in China in early 1994, the claimed goals for microfinance have always been around the mission of poverty alleviation.

The State Council Leading Group Office of Poverty Alleviation and Development (CPAD) was established in 1986. Since then, various policies and measures have been put into 
practice for poverty alleviation. The formation of CPAD set the structure of poverty-alleviationagenda for the next decade until today. The primary level of poverty alleviation is at the county, and financial aid from the central government is distributed by the provinces. In 2013, Chairman Xi Jinping proposed the idea of "Poverty Alleviation with Precision" or "Targeted Poverty Alleviation," and this has ever since been a central political task for various government and government-affiliated institutions from various levels. A significant consequence of the "Poverty Alleviation with Precision" proposal is that poverty-alleviation is seen not only a political task for local government institutions - such as the Bureau of Poverty Alleviation and Development (fu pin kai fa ju 扶贫开发局) that are directly responsible for welfare in poverty-stricken areasit also becomes a political task for many other government institutions or government-affiliated institutions. "Poverty Alleviation with Precision" means targeting the obstacles in a poor household that prevent economic advancement, and all government agencies work specifically to help the poor. In practice, it requires a government worker or civil servant from a government institution being responsible for a specific household in carrying out specific tasks such as measuring and recording the household's economic situation and giving specific assistance on behalf of the government. There is an evaluation of how these practices succeed, and such assessments are an incentive for local governments make this work a priority Under the lead of CPAD in the past near four decades, there have been attempts of poverty alleviation on all kinds of dimensions which included some financial mechanisms such as interest-subsidized loans, as well as some microfinance programs (Wang 2008). Before introducing Better Life MFI's program (established in 2014), it is worthwhile to mention a more general policy initiative, "Financial Inclusion," which has become more of presence in the financial markets in China. 
Financial Inclusion in its general meaning is a state ideology that deepens and expands financialization. In 2013, during the 18th meeting of the Central Committee of the CPC, Financial Inclusion became a national strategy. At the end of 2015, the State Council published Development Plan of Progressing Financial Inclusion (2016-2020). Today, Financial Inclusion is a well-known policy guide that is deeply employed by financial institutions at various levels.

Financial Inclusion's mission covers not only microfinance or microcredit, but also savings, insurance, and the most recent digital and mobile payment services. Under the umbrella of Financial Inclusion, small-to-medium businesses, middle-to-low income groups in both urban and rural areas, seniors, people with disabilities and other marginalized groups are theoretically all new beneficiaries of financial markets. For rural China, Financial Inclusion is realizing its goal of covering remote rural areas by setting up branches, mobile service stations and cashwithdraw services in remote rural areas. By the end of June, 2019, the officially-reported coverage rate of financial institutions in rural areas nationwide was $95.65 \%$ (that is, the numbers of rural areas that have financial institutions or service branches), thereby making financial services more accessible for many rural populations (Financial Inclusion Report of 2019).

In May 2017, Chinese premier Li Keqiang asked big commercial banks in China to set up a Financial Inclusion department. the Big Five ${ }^{2}$ national commercial banks first established inclusive finance section in their headquarter offices within two months after the announcement from the premier. "Through the development of financial inclusion, (we will) increase the coverage and availability of financial services, and offer effective support for a real economy," said Premier Li Keqiang.

\footnotetext{
${ }^{2}$ The Big Five national banks in China are the Agricultural Bank of China, Bank of China, Industrial and Commercial Bank of China, China Construction Bank, and the Bank of Communication.
} 
It was in this environment that the unique collaboration between the Better Life MFI and the China Enterprise Bank (CEB) developed. The China Enterprise Bank has financial inclusion listed in its social responsibility report. Besides providing more accessible financial services to rural populations, the $\mathrm{CEB}$ also gave out loans to small to medium- sized enterprises, "quick loans" to small businesses, and loans for laid-off workers who aimed to start new businesses as part of its financial inclusion achievements (CEB CSR 2018).

\section{History of Microfinance in China}

At the end of the 1970s, China implemented the "Reform and openness" policy which guided the country's economic development, while leaning heavily towards market-oriented economic development. In this context, rural China was considered to be "backwards," and lacking modernization and progress. Microfinance is an example of the national economic development policies designed to integrate rural China into the relatively more developed urban economy (Loubere 2018).

The development of microfinance in China started and expanded in the mid 1990s. In 1998, the leader of the CPAD from the State Council advocated the expansion of microfinance in China: "Microfinance is an effective tool to reduce poverty. We should experiment with microfinance projects in some areas and then spread these projects to other areas. They key characteristic of microfinance operations is that funds directly reach the poorest rural households and that the rate of repayment is high.” (Du 2004) The first China Microfinance Summit was held in 2003 with representatives from the Ford Foundation, the Citi Foundation, as well as attendees from over one hundred microfinance programs in China. The China Association of Microfinance (CAM) was established right after this summit in 2005. It is a cooperative, selfregulating organization aiming at promoting the development of the microfinance industry. CAM 
claims that the organization introduced and promoted the concept of financial inclusion, which was presented as a resolution at the Third Plenary Session of 18th Central Committee Meeting of the CPC, and also became the focus of the State Council's financial reform (CAM Annual Report 2018). The establishment of the CAM and the advocacy agenda in its organizational mission was turning point in the promotion of microfinance, using the financial inclusion mandate to solve rural poverty issues in China.

The academic discussions and practical implementation of microfinance in China are mostly carried under the name of Financial Inclusion. Among the policy makers and regulatorsparticularly, the central government (State Council) and central bank (People's Bank of China), and the central bank regulator (CBRC) - it is seldom questioned if the expansion of financial services to rural China is viable solution for rural economic development. Many financial inclusion projects and initiatives have been carried out with great enthusiasm in recent years. However, the recipients in the mechanism of microfinance — borrowers, usually the rural villagers - are rarely the subject of sufficient consideration in microfinance product design. In contrast, the discussions about microfinance in China are mostly around the following things: how to control the credit risk (that is, protecting the financial institutions), how to increase or balance the demand of credit in rural China (which implies the idea to deepen the financial services and to expand credit market), and how to increase the farmers' credit consciousness (with the assumption that farmers are in need of financial education which the policy makers think are a necessary skill).

\section{Expanding the Debt Market in China}

Although the first few experiments with microfinance in China was conducted in the early 1990s (Du 2004), the economic environment for microfinance programs to flourish did not 
mature until later, when the credit market become stimulated in China, and when loans become a ubiquitous tool for people who needed to access additional capital.

The "Asian Index of Financial Inclusion Ecosystem" assesses the overall situation of the financial inclusion ecosystem of sampled Asian countries (according to the Boao Forum for Asia) and China is among the high performers in this index (China Daily Newspaper 2020). As China steps into a more "Financial Inclusive" stage, the financial market that needs to expand is the credit market (Fungáčová and Weill 2015). The most significant change in everyday life is the prevailing personal loan and credit market expansion in recent decades, as technology advances in this field.

Today, credit platforms in China go far beyond the traditional financial institutions, such as commercial banks. Credit products from online retailers such as the Alibaba Group and the JD Group are common ways of financing consumption demand. Random advertisements for "Quick Debt" and "Easy Debt" are visible everywhere in urban and semi-urban China, including virtual spaces and social media platforms. Under this situation, multiple forms of alternative credit services have become accessible to many people, with a visible emphasis on online credit platforms. It should be noticed that these consumption-oriented loans are relatively new (since the ten years), but they are now widely accepted and used in even this rigorously-controlled economic environment in China. Meanwhile, because of the rapid growth in the "internet finance" field, these relatively new credit platforms, such as online retailers, are lacking strict regulation, which puts them under less pressure than commercial banks (Chu 2014).

Access to small or large loans also expanded in recent years, especially with the advent of online P2P (peer to peer) lending platforms. P2P lending was introduced to China in 2007 and has witnessed a dramatic growth after the development of internet finance in 2013. In its peak 
years, the P2P industry in China was the top in the world in terms of the amount of the platforms available and scale of loan (Yin 2018). However, the P2P industry had a low entry barrier and regulations targeting P2P were not put in place as it expanded. Problems become apparent in this industry as poor or fraudulent cases, developed one after another. Later, as the P2P industry collapsed in China due to all kinds of problems, regulations on credit markets begin to tighten the credit environment (Yin 2018). What destroyed confidence in these credit platforms were infamous cases such as various Ponzi schemes related to P2P (Yin 2018). Yet, in general, the credit market in China is expanding in different forms and at rapid speed.

In this environment, microfinance programs, which aim to offer financial services to the poor who have no access to formal credit lines, have particular challenges. These challenges are unique to the specifics of microfinance because of its format and mission.

First, because of the fraud and complexities of exotic credit schemes just mentioned, people now are generally suspicious of any loan that come from unfamiliar channels. Microfinance institutions are not established in the public's imagination, and do not yet have established reputations. Borrowers often question the legitimacy of this loan because of the group-lending format (a fact confronted by Better Life numerous times). Because of these suspicions, MFI workers have to present themselves as respectable professionals working for a recognized organization.

Second, microfinance needs to stand out among all the available credit products if it intends to gain clients in an increasingly-crowded market. This is often justified by MFI top leaders by the mission statement: "Poor women who have no credit history should be the ideal client group, because they are the truly unbanked. People who already have access to capital are not our clients." Yet, in practice, as we will see, MFI workers have their own KPI pressures in 
this job, and recruiting women who need cheap loans becomes the primary goal, rather than waiting to recruit the "ideal" clients.

In this ever-expanded credit environment today, how microfinance distinguishes itself and justifies its development mission appears to be evolving; and currently there are now different interpretations of microfinance.

Microfinance today in China is taking on the policy mandate of financial inclusion, which is an extension of the general financialization happening in contemporary China today. In the meantime, microfinance faces competition from other credit products that are prevailing in China now, with the help of mobile financial apps such as Alipay. The efforts to justify why microfinance is something worth doing is often discussed by the Better Life workers in following chapters. It is within this background that I begin the next chapter's analysis of the MFI workers' everyday work, their aspirations, and interpretations of what their job is. 


\section{CHAPTER III: REDEFINED DEVELOPMENT AND WORKERS' TENUOUS POSITION}

Staff members at microfinance institutions (MFI) are the workers carrying out the frontline routine of recruiting borrowers, conducting training activities, holding weekly meetings with clients, and collecting repayments. They are named differently at different MFIs, such as loan officer, adviser, or center manager. It was when I interviewed with Better Life for an internship opportunity that I decided that understanding microfinance from the staff members' perspective would be a fruitful and revealing way to examine MFIs. I noted to myself after the interview that while everyone is doing "something" for a living, this "something" may be a task that feels right and good, or a be task that is just a means to make a living. I wanted to know why the workers came here to work and what aspirations do they bring at this job.

In this chapter, I will start with the compelling questions of the aspirations of the workers: Why did they enter the world of microfinance? Do they believe in microfinance's goal of poverty alleviation while they entered this career? Does carrying out such a mission matter? Then I will move on to the present practices of microfinance in the daily interactions. From these practices, I hope to show the kind of "tenuous position" MFI workers are in (Kar 2013), and why these tenuous positions lead to particular kind of microfinance practices. This chapter then concludes that the tenuous position of MFI workers has a great deal to do with the social context of microfinance, and the debt market in general. The mission of microfinance is hard to be fulfilled when the tension between debt and development in microfinance is not resolved at workers' minds or their interpretation of the job. In actual everyday practice, believing in working towards a grand and benign mission—such as alleviating poverty or empowering women — is not particularly important. More often, the everyday pressures come from how to 
recruit more qualified borrowers, a KPI issue that is faced by most modern enterprises with prioritized business goals.

\section{Aspiration While Working at a Microfinance Institution}

Situating the MFI workers in their own socioeconomic and cultural context matters, because their aspirations of this job have a lot to do with their background. The background of different CMs vary greatly across different sites internationally. In Schuster's study of microfinance in Paraguay, MFI workers were young, socioeconomically disadvantaged, employees who were enthralled with the entrepreneurship (Schuster 2015: 56-61). However, in Beck and Radhakrishnan's comparative study of two microfinance programs at Guatemala and India (2017), those workers were well-educated employees.

In my field site at Better Life, the backgrounds varied greatly even sometimes within the same branch. Most of the CMs hold bachelor's degree as it is part of the requirement for this position at Better Life. A few have master's degrees, or have graduated from prestigious universities in China or abroad. The college majors of the CMs at Better Life is diverse, ranging from majors such as social work, sociology and psychology (listed on the recruiting website as desired majors), to economics and finance, human resources management, accounting, media communication.

Nearly half of the CMs in Better Life grew up or came from rural households, and the rural background or passion for rural life and people is viewed as a significant factor in job interviewing. In a public lecture about microfinance and social work, the president of Better Life was the speaker giving his view about microfinance from the perspective of social work. One audience member raised a question: what kind of candidate is preferred for this position? The 
president didn't name specific desired characteristics but answered this question with deep sincerity:

One must like the rural life, and love the people living at bottom. When you talk to the women, your eyes must have the warmness inside and talk like you're talking to a family member. Don't join Better Life with a utilitarian mind ... If the candidate is from the rural area, I would ask him or her what's your impression of your mother, what kind of rural labor have you ever done, and what's your memory about rural life ... These are the things I care the most.

The passion of rural life and sense of responsibility for changing rural poverty is viewed as significantly important in the top leader's mind. However, this is not emphasized in the branch manager's views about the most important characters for working in microfinance. Being in the middle level, between the top leader and the staff members, the branch manager captures the dimension of the "business professionalness" of this work:

Having that mission or faith is not that important actually; the most important thing for a $\mathrm{CM}$ is to follow the guidelines well. As long as they do as the guidelines say, it will work well. Eventually, the CMs would begin to reflect on their work's meaning and begin to think about the mission part. But I don't worry about them coming in with no mission; it is their executing ability is the most important.

Based on some similar interpretations as this one, microfinance is seen as a specific wellrounded technique rather than a calling. This is not without a precedence within the international of microfinance in general, especially since the fame gained by Grameen Bank in Bangladesh: that "technique" itself is like a science, which works consistently and smoothly if it is followed step by step. It will work as long as the procedures, details, and principles of how to do microfinance are followed correctly by the workers. Under this interpretation, microfinance is seen as a well-rounded technique or theory itself, and the missionary spirit is not so important.

From these contrasting points of view, it becomes clear that different actors in the microfinance industry would emphasize different key elements of an ideal candidate profile. This 
contrast between the views of the branch manager and top leader illustrates an important question that will be addressed at the end of this chapter, after discussing the tenuous position MFI workers find themselves in: does one have to have the missionary spirit of changing the world to do a good job in microfinance? Or it doesn't matter in practice?

We saw the desired qualities for an MFI worker from the management level. What about the views of the MFI workers themselves? I will now turn to the voices of MFI workers on why they come here to work, and what do they hope to achieve from working here. Specifically, there seem to be three main reasons of entering the world of microfinance: 1) to escape from the 'dirty' financial world they used to work in; 2) to change the world by helping the disempowered; 3) to just make a living. These reasons can overlap, of course. But these three are the main motivations that differentiate their purposes and long-term goals of MFI workers.

\section{A Clean Space Compared to the Dirty Finance World}

A few workers had finance and banking careers before joining BL. They come to BL because it is a much "cleaner" space, compared to the environment in traditional finance circles: "This program is closer to altruism". For these workers in MFI, microfinance, which carries the ultimate goal of alleviating poverty, is interpreted as a "clean" space for doing finance. This "clean" space is a mental metaphor workers at BL use to distinguish the work done at this MFI from the work done in their previous career in finance, which is viewed as "dirty" compared to microfinance.

I indeed don't want to work in the financial industry anymore ...(which is all about) thinking about how to charge the $2 \%$ (commission) fee all day... The reason why I joined Better Life is to change my circle. I don't want to stay in the dark finance circle. I saw how everyone at each branch thought about how to help the members' businesses. I would feel this is so meaningful. Andi, management level employee at Better Life 
Similar to Andi's emphasis on work helping women borrowers, a new employee

Tianchen (who was in his first day at the time when I asked him how did he feel about the work at first day) also focused on the work content:

I have worked in commercial banks for six years. This afternoon, I was visiting shops with everyone and I felt the difference of working here is ... It's not just about debtor and creditor relationships, it also means friends ... [The workers think about] how to help them [the women borrowers], and how to [help them] do the business better, this is also what attracts me [to work here]. At any industry, as long as [people] put their heart into the work... it's just serving different groups of clients.

Tianchen, new employee at Better Life

In Tianchen's and Andi's perception of this job at BL, microfinance represents a way of doing finance with a moral purpose. Their career trajectory of working here in the microfinance industry after their previous finance and banking career is only chosen by two CMs among the Better Life employees, but it represents one unique type of motivation for working here. This unique motivation of working in microfinance after a more general/traditional finance and banking career is demonstrates these workers" tendency to distinguish this "micro-finance" (specially the Better Life model) with other general finance.

\section{A Humane Job to Change the World}

Most senior CMs, who have either worked here for more than three years or have become a branch manager, and other senior level employees, because of extraordinary education or experiences, have a clear and determined idea about why they work here. They are here to make some contribution to changing the world, a world with less poverty, a world with more gender equality. They believe that working in Better Life is a way towards the achievement of this goal. For these workers, the most important aspiration of working here is to achieve some personal 
goals towards making a better society. Among them, most interpreted microfinance as a "human job":

There is a lot of human investment in it, such as emotion, and sensitivity. No machines or algorithms on giving loans can replace this human job.

CM, Shasha

Many senior CMs and branch managers define their job as a humane job that deals a lot with people. The quote from Shasha came after my question about the competition from other online loan platforms such as Alipay's credit products. Shasha told me with determination and confidence that "Those easy loans on Alipay... no actual human is behind the algorithm, like us walking to the shop, visiting and talking ... There is a lot of human investment in this, such as emotion, sensitivity. No machines or algorithms on giving loans can replace this human job." In her emphasis about microfinance's distinctiveness as a human job, Shasha elaborated on her faith in microfinance, as much as her faith in human job over machine job. Those human-centered characters are cherished by these workers as they see themselves realizing some social values of this job through working with people.

Similar elaboration of the "human job" trope was heard when I asked another experienced CM, Zeli (who was already a branch manager by the time I was talking to her), what is the most important characteristic for doing this job.

We deal with people mainly in this job... It mostly relies on how you work with people...

CM, Zeli

Zeli is one of the few experienced employees at Better Life, and she has already climbed up the ladder in this MFI by being a branch manager by the time I arrived at the field site. She has gained deep insights about the operation of MF and most often she would give examples to 
illustrate the importance of human input, or emotion and sentiment. By emphasizing the "human" element, some of the staff at Better Life found a purpose in this job, giving meaning to their lives, and doing something consistent with their personal values.

\section{Only Another Job So I Can Eat: No Mission -Spirit Needed}

Several CMs shared different stories of how they came to work at BL. For them, it is a job that was found on a job website only; to them it is just another job, allowing them to feed themselves and their families. They did not join BL with a social strong commitment or desire for poverty alleviation. Nonetheless, they were hired because they are good with people, understand basic financial concepts and knowledge, and — most importantly—-they follow orders well and do as they are told.

As one branch manager believes, the developmental-mission of, or faith in, microfinance is not important. Instead, the ability to learn from training sessions is more important:

Some people come here not necessarily with some ideals about society (or a mission to change the world). I have confidence that, given enough time, people with good character would do this well, after training ... One does not have to believe in the Better Life model to do this job. Our training tries to make people believe and recognize this - to make people have faith in this model. But it's not a must.

CM, Zeli

When CMs join Better Life, they didn't necessarily carry the missionary spirit or even think much about it. It is a job for survival, first. Shasha joined because this was the first job offer she found comfortable accepting after two months of looking. Her first job in human resources was not a suitable for her even though that was her college major. Taotao and many others joined because they found BF job offers online when they were looking for a job close to home. Neither Taotao or Shasha ever told me that their passion for development was a reason for joining Better Life. However, Shasha's view about why she works here has been evolving ever 
since she started, and she has been at Better Life for a long time. As seen in her explanation above, in her elaboration on why microfinance is different from other credit products online, Shasha has a clear idea about what the job entails as, she has spent more than three years here.

Perhaps Shasha is an example of successful microfinance training that allows workers have faith in microfinance, as a model and product. However, for some others-especially local employees who rely on this job only to feed their family — this job does not necessarily hold any personal value or a passion for poverty alleviation. As Heming said casually after one training session: "I just hope that our company doesn't go bankrupt, so I can still have a job ... I need it to feed my family." Although his tone was casual and joking, he is probably expressing his true concern for the company's long-term stability. After all, he is a father of two children.

\section{The "Ethically Tenuous Position" of Workers in Microfinance Institutions}

When the anthropologist Sohini Kar was doing fieldwork about microfinance in urban India, she used the term "ethically tenuous position" to describe the dilemma microfinance loan officers were facing: asking for repayment of a loan from someone who clearly cannot repay, or else damaging their credit history or social standing by recording their debt as unpaid (Kar 2013: 480). In the microfinance practices I studied in China, the MFI workers didn't quite encounter this specific dilemma, but their positions are similarly tenuous because of the following aspects: 1) they are often viewed as money lenders; 2) they often feel bad about letting the borrowers down of the microcredit transaction for some reason fails. Therefore, I called this section the “ethnically tenuous position" of microfinance workers, building on Kar's work in India (2013).

\section{Avoid the Image of "Just Another Money-lender"}

At Better Life, the workers have a specific title: Center Manager (CM). This title doesn't really connect a credit officer (or anyone with a similar job title) debt obligation. In this sense, 
the job title is not especially meaningful. "Center" is the name of, and a key word for, microfinance social-group structures. Five women form a group, and then multiple nearby groups from one of these "centers." The Center Manager (CM) is the primary person organizing and holding the weekly meetings (called "center meetings") for the groups and the centers. On one level, this is what MFI are emphasizing in their work: the CM is the primary person taking charge of each center, which is made of several groups of borrowers. On another level, this avoidance of mentioning the actual debt relationship in the job title is helping the CMs work smoothly with less barriers than if they were thought of as mere money lenders.

This is a common response when a CM tells their family or friends what their job is: "Oh, you are a money-lender (放贷的 fang dai de), then.” The image of a money-lender is not necessarily negative, but recent events regarding fraud, lending schemes, and financial shenanigans have made many people suspicious about money-lenders. Many online lending schemes that eventually defaulted have now made money-lenders infamous. Therefore, a moneylender may not only be looked down upon, they may face outright social or professional rejection.

Another image CMs are often associated with is door-to-door salesman. Selling door-todoor is a business strategy that aims to sell products directly to households. However, it often has a negative connotation, because people generally find these salesmen disrupting and unwanted. CMs' work routine is very similar to door-to-door sales because their primary strategy is to recruit members shop by shop, face-to-face.

This happens almost every day when the CMs try to recruit more borrowers by visiting each shop, one by one, street by street. It is very common for a shop owner to be indifferent when the CMs start out saying, "We have a loan product that ..." This promotional style 
occasionally incites threats of physical threat towards CM. There was one time when two young female CMs were slapped when a shop-owner didn't want to hear any more of the sales pitch. It brought the CMs to reflect afterwards on how they should talk about their product without bothering or irritating the potential clients, and most importantly, asking themselves, "How should we manage our own emotions better when we face rejection or misunderstanding?"

The label of “money-lender”(放贷的 fang dai de) and “door-to-door salesman” (推销的 tui xiao de), then, are two typical responses microfinance workers experience daily. The developmental mission behind the product often doesn't help clarifying this image; on the contrary, it might potential clients even more suspicious, especially when forming groups of five people is mentioned (which is hard to justify at first. "Who are you?" is common response. Some CMs told me that they would rather not to mention the five-people group formation at first because people often get suspicious about this initially.

However, some CMs explain the distinctive characters of this product by introducing the group-formation component in their sales pitch — as an attempt to show the unique nature of this product (using a sales pitch described previously on pages 13 and 14). Some people are fine with this component — at most, finding it "troublesome"; yet other people are hesitant about this group-formation aspect, and continue asking more questions (mostly to confirm that they will not be obligated for others' debts). Group-lending is one of the central features of microfinance; yet it is viewed as a weak point in the sales pitch, and CMs would often borrow other terminology that is related to general microfinance policy from the government to help clarify why they are promoting this product. This often effectively wins the trust of clients, when they hear it is a product offered under auspices of the government. 
CMs in Better Life often mention the key words such as “policy-based loan” (政策性贷 款 zheng ce xing dai kuan), or “loans for poverty-alleviation” (扶贫贷款 fu pin dai kuan)” which, in a way, helps distinguishing this loan product from other loans because these policy loans are already well-articulated by Rural Commercial Bank when they were giving out some interest-free loans under the earlier policy initiatives. These terms are generally associated with some welfare products government introduces to people. Therefore, CMs strategically borrow these terms to justify the financial features in this product: "Yeah, this loan has a fairly low interest rate because this is a policy-based loan, indirectly supported by the government." People mostly react to these government policy loans with a sense of trust and preference because those are backed by government. Although in this case this loan doesn't directly come from the government-it is at most a loan that is consistent with the government's policy on poverty alleviation and financial inclusion - people are generally accepting.

Another way CMs polish their image is to mention the product's relationship to the CEB (China Enterprise Bank). (CEB is the pseudonym for the bank Better Life is collaborating with). The CEB has its own reputation as a more well-known bank than Better Life, which suggests that BL is trustworthy and reliable. "We are from the China Enterprise Bank" is often the first line in a sales pitch. In this way, CMs find there is less doubt as to who they are. However, some might people ask something further: "Are you really from CEB?" Then the CMs have different responses. Some would keep defending their identity as CEB employees, believing that "We are paid by CEB, so how can we not be a CEB employee?" Some CMs would explain things this way: "We are from a specific section of the CEB responsible for this Women Entrepreneurial Loan." And some CMs would directly say: "We work in cooperation with the CEB on this program, and all these loans are made to borrowers by the CEB. You will go to CEB with us to 
do the loan approval interview. How can we be liars if we meet you there and work with you at every step in the loan approval process while the CEB staff is also there? We are paid by the CEB to apply this foreign model to rural China. It's just a technique, not any scheme. We offer this product in as consulting firm for CEB." With these clarifications, CMs try to maintain a more upright and legitimate image even if their identity as a CEB employee is questioned. Some potential clients still have doubts after hearing these explanations, and some later went to a nearby CEB branch to confirm whether this product is authentic and actually come from CEB. Staff from CEB are trained to be aware of this microfinance product, which helps Better Life building credibility after women borrowers confirming their authenticity.

As seen here, in their daily routine of promoting themselves, doing sales a pitch, and interacting with potential women borrowers, the CMs have multiple layers of barriers to conquer when they try to deliver this "benevolent" financial product (at least in the minds of some CMs) to women borrowers.

MFI workers at Better Life, then, have developed various ways describing, and successfully promoting, their product. including: distinguishing themselves from money-lenders or door-to-door salespeople, clarifying the purpose of group-formation, justifying the purpose of this product using key words related to government policy, making self-introductions about coming from a big national bank $\mathrm{CEB}$ as a way to gain more trust.

They understand the realities of the low trust from potential clients in this environment. The perceptions people hold regarding financing, loans, and credit and debt are inevitably significant factors in shaping what kind of particular microfinance institution this is and what kind of people the workers are. In after-work conversations, MFI workers at Better Life would reflect on the distinction between themselves and other loan officers, saying, "Our actual 
practices make us distinct from other kind of loan offers. ... What distinguishes us is the social support we give to borrowers, compared with other banks or loan institutions."

The kind of patient attitude MFI workers hold is not unique to Better Life. Anthropologist Sohini Kar, who has studied microfinance in India, has similar stories about workers" "Gandhian" attitude (Kar 2013). After the "microfinance crisis" in India, women borrowers asked the branch manager why they could not get new loans. In very brief, the "microfinance crisis" in India was a series of microfinance-related suicides that attracted government and media attention, which made banks unwilling to lend to MFIs (Kar 2013: 481). When facing the situation of not being able to offer loans to women borrowers, especially having no good reason to tell the women borrowers why, a worker from this MFI found himself helpless and became afraid that women borrowers may stop taking loans from them (Kar 2013: 490). In an effort to explain why the women couldn't get new loans recently, the branch manager explained things in a way to distinguish their MFI from other moneylenders: their lack of violence in repayment collection, as opposed to the violent way typical of moneylenders (Kar 2013: 486). In the narrative of the MFI worker talking about their relationship with borrowers, MFI workers, have to be "Gandhian," meaning "No matter what they [borrowers] say, we just have to listen and wait" (Kar 2013: 486). This moral ethic not to use violence in pressuring for repayment became evidence for the branch manager to articulate the distinction of microfinance from moneylending. By emphasizing the patient attitude of MFI workers towards borrowers, MFI workers see that sometimes they make personal sacrifices for their job and their clients.

In the context of China, workers at Better Life also faces similar problems when they walk to shops, door by door, introducing and promoting the microfinance products. MFIs rely on their workers walking on foot to deliver and clarify what kind of service microfinance institution 
is offering, and what kind of organization the MFI is. Ever since the beginning, MFI workers do not simply carry out the tasks as described in their job descriptions- that is, mainly technical and operational tasks - they also carry the additional duty to clarify the image of the MFI they are representing to potential borrowers, while bearing possible verbal abuse from people that view these MFI workers as sent by moneylenders, or as people selling some kind of infamous debt product.

\section{Letting the Members Down after Loans are Rejected by CEB}

In the CEB's screening process for loan application, good clients have a good credit profile which is demonstrated by the Social Credit Report. Social Credit Reports are a relatively new, but powerful and massive system, that has the basic personal information and credit history of every citizen who has credit history in China. Established by People's Bank of China, it is sometimes called an "Economic ID card for everyone" (Social Credit Report website). The screening process of the CEB is like many other traditional banks: what is preferred are no additional or other large outstanding loans, and a sufficient amount of stable income. However, after a loan application being rejected by CEB loan officers, it becomes a negotiating and compromising process for workers at Better Life.

CMs at Better Life had great autonomy and power in the loan approval process in the previous cooperative program with a local bank. However, that is not the case for the current program, in which the final loan approval is done through layers of the CEB screening process. After several rejections and return of loan application documents from the CEB, CMs gradually understood the process better and developed their own pre-screening standards based on their previous experiences with CEB loan officers. 
One CM once shared in a meeting that "We have a totally different perception of the borrowers than the CEB. We see them as trustworthy, naturally, but the CEB sees them as risky, naturally. That's just the different perceptions." However, these reasons for rejection reflect typical risk management principles, so it is natural from the CEB's standpoint. But it also shows how, gradually, the MFI workers at Better Life began to adapt to and adjust risk management to raise the approval rate of loan applications from the CEB:

The working address (of a hospital) in current Social Credit Report is different from where she is actually working now (a small accessory store). We just thought it was a previous address of where she worked before, so no problem. But this is considered to be lying at the CEB because they think she is trying to show she has a stable income from the hospital to raise the possibility of getting the loan.

- Aiyi, branch manager at Better Life

We need to calculate the ratio of debt to income before we submit the form to the $\mathrm{CEB}$, as a pre-screening step to make sure the borrower has enough to pay back the loan(s).

— Lulu, branch manager at Better Life

We need to familiarize ourselves with the calculation of debt ratio, monthly income and expenses, assets etc. This is all important information on the application form.

We need to check their social credit report carefully. Do they have credit cards? What's their repaying pattern? Do they use one card to repay for another card or loan? We have to be careful in checking these things.

— Aiyi, branch manager at Better Life

Some people already have a lot of debt outstanding, that's not from us.

— Bian, branch manager at Better Life

The new rule from CEB: If an applicant has consecutively three times been overdue in five years, and one time overdue in two years, then the loan will be rejected.

— Lulu, branch manager at Better Life 
From these selected quotes, that are just portions of daily conversation after hearing why some loan applications were rejected, it is clear how workers at MFI are constantly adapting their own screening criteria. The CMs are assimilating the 'foreign' CEB lending criteria that is alien to BL's mission (which actually hopes to lend to financially excluded groups).

Meanwhile, MFI workers at Better Life need to deal with the reactions from borrowers after they are informed that they have been rejected. In most cases, the borrowers themselves don't ask for too much justification and accept the result. But what needs to be kept in mind is that there has been a significant amount of work done prior to submitting the loan application, such as five day-training program, and multiple visits at the borrower's shop to either persuade them to join the program or help them fill out the forms (with quite detailed questions about financial conditions, family situations, etc.). Some CMs personally feel bad for not being able to get the loan approved for the applicant after so much work. They would sometimes feel sorry meeting the person on street, especially when they feel helpless for the borrower when working on a possible new application. Mainly they feel bad because they have shown so much certainty to the borrower about the loan, and occupied so much of the borrower's time in the process, yet it ends up being vain.

These tenuous position of MFI workers not only show that microfinance has all kinds of barriers when promoting loans (due to the specific social and cultural understandings of loan), but also the deeply-rooted irreconciliation of the financial features of debt, with the developmental dimension of microfinance (such as the inherently different risk-profile perception by the CEB and by Better Life). 


\section{Contemplating and Redefining Development}

"Our ideal clients are poor women who have the determination to work hard for a better life of her family. She would be willing to work hard to gain income for her kids' education, for her own wealth, and her family members' health ..." I didn't have a clear picture of an ideal member profile until I attended several training sessions, and heard the comments from CMs on their understanding of ideal members. However, the pressure on CMs are often not on where to find the ideal members, but how to find someone just enough good as applicants for loan applications. "Enough" is to satisfy the goal set by their cooperative partner, CEB, on their annual loan distributions. "Good" is to go through the screening process of the CEB loan applications successfully. "Enough good clients" are not exclusive with "ideal member," but the microfinance worker's focus and orientation are often placed on seeking "enough good clients." For example, some members may not be qualified as poor women, in terms of assets owned.

Although not every CM has deep insights and thoughts about the Better Life model they are following, some CMs show deep concern about the contrast between the original model versus the current practice. The most often-perceived pressure of this work is the KPI (key performance indicator): the measure of the amount of loans distributed and how successfully they performed. This is almost identical to a sales goal (just a loan-amount goal in this case) set by the CEB. However, not every CM has the same skills or talents in "sales".

Under these conditions, there is a presumption that the original model itself is a wellrounded, complete and consistent system. The original model could have achieved success in its mission. However, CMs feel that the current practices are not always consistent with the original model.

What Better Life is doing right now is still just loan services only, not like the original model. In the Home Office, the "Country" is a complete ecosystem, 
such as services of seeding, telephone lady... which directly give members support on making a living. Certainly, that has taken a decade and even more than twenty years. The current model in China is compromised. Because what

we are doing is limited by the CEB's requirements, this make us not too different from other banks' loan approval requirements. This can't show the advantage and uniqueness of Better Life in short term. Perhaps Better Life will have to make a balance between the short term (high efficiency in giving out loans) and long term (giving members social support).

Shasha

What makes Shasha compare the original model and the current practice is, in my opinion, why she joined Better Life. Although she didn't necessarily come in with the missionary spirit either, but she has a very curious and diligent mind and keeps asking questions in her work. After more than three years' working experience at Better Life, she is a firm believer in the original model, and often gives her own family as example to illustrate the meaning of social capital and the consequences of a lack social capital. Yet there seems to be a conflict between short-term and long-term goals for Better Life in CM Shasha's reflections. This is not surprising given the tensions microfinance has to balance: the focus of their work should be about giving out many loans, or giving help to the few ones who need it. The right level of intimacy and distance for MFI workers is a difficult balance.

\section{Conclusion}

These additional efforts that is meant for achieving the developmental goals of microfinance are dependent on personal moral characteristics, professional understanding about this work, the culture at the MFI, and even the world view and aspiration of MFI workers for the job. This is closely tied to the social development goal of microfinance because these inputs affect the output of microfinance's mission. However, relying on the personal characteristics of the MFI workers is not sufficient or sustainable for its developmental goal. Their efforts and input could fulfill the temporary needs of capital for business continuation, then training, and 
information sharing on other "better life" dimensions. But these efforts lack the fundamental agendas — such as women's empowerment, gender equality, and poverty alleviation - that are the theoretical reasons for establishing microfinance in the first place. This perhaps shows the inherent deficiency in microfinance, in that it is used by women borrowers primarily for temporary capital needs, not for the social development dimension microfinance aims to eventually achieve. It is not surprising that these tenuous positions discussed in this chapter lead to compromised development accomplishments, and the aspirations of working as a MFI worker further attest to this.

The realities of MFI workers' tenuous position, in relation to their aspirations for working in microfinance reveal the contrast of ideals and realities. By displaying the contrasts here, I have attempted to show the purpose of microfinance, give an evaluation of its helpfulness, and explore the meaning behind the job as articulated by workers. These contrasts serve as the key for understanding workers' role in microfinance. In the contemplating and redefining development section, I show the answer from workers about what microfinance is for. Through the expression of the MFI workers feelings on the development dimension of microfinance, it becomes clear that workers are interpreting and measuring the success of the MF goal of helping poor women from primarily two aspects: 1) giving loans to people who need capital; 2) bringing social capital and support. In practice, as long as people use loans for their business, and find friends and support after joining a loan program, it is considered to be a successful example of microfinance to them. Perhaps the long-term goals—-such as gender equality, and poverty alleviation — are also interpreted in this way, but it's not as promising, because the short-term goals could be measured in front of people's eyes and with media stories. With this redefining process, microfinance presents a successful image about its effectiveness. This achievement is recognizable. Yet it is 
not really due to its financial features (given that loans are easily accessible to many people in China with the loan platforms), but the social-work component accomplished by microfinance workers. Microfinance still needs to bring in, or advocate for more, fundamental changes which microfinance itself—with loan features only—can't achieve. 


\section{CHAPTER IV: RELATIONALITY IN THE WORKER AND BORROWER RELATIONSHIP}

When it comes to understanding the role MFI workers play in this extending-to-the-poor financialization process, it is important to understand the perspectives, articulations and practices from workers (as shown in Chapter 3). It is almost equally significant to also ask what kind of meaningful relations have occurred in everyday interactions with borrowers. MFI workers' roles and influences in this financialization process are embedded in the daily interactions between borrowers and the workers, situated in the financial relationship that are linked by the loan product. The role MFI workers play has a lot to do with the kind of relations formed between workers and borrowers. More specifically, financialization (the expansion of finance to those previously excluded, specifically poor women) is a process shaped by these distinctive and meaningful relationships.

Based on these concrete roles MFI workers play, "relational work" is an useful lens to understand what these roles and relations mean in financialization. Relational work points out the inseparable nature of the economic sphere and the social sphere (Zelizer 2012). Relational work could further explain the non-financial relations between workers and borrowers in microfinance. In this Chapter, I will first show the kind of "ideal" relations imagined by the microfinance designers, MFI leaders, and MFI workers. These ideal relations surround three key orientations: professional, guiding, and intimacy. Then I will use Zelizer's theory of relational work to analyze specific stories of relations that actually occurred in the everyday interaction between MFI workers and women borrowers. This serves as a comparison to the imagined relations first mentioned, and also demonstrates the perceptions from the workers regarding their relations with members/clients. Lastly, I will show how discussions among MFI workers regarding the microfinance product itself shows the internal thinking and hesitations MFI workers hold 
towards the loan-product features of microfinance. Throughout the chapter, relational work is the central analytical framework to show the blurriness of social and economic meanings in microfinance. Through relational work analysis, I will identify the media, transaction and meanings in each specific relational story described here. By doing so, I will demonstrate the different effects on doing microfinance when workers carry distinctive meaningful relations with borrowers.

\section{Imagined Relations in Microfinance}

Better Life has specific requirements and expectations for CMs when they give training to CMs. The following are examples of strictly restricted behaviors: accepting food, water, or gifts from borrowers, or developing any romantic relationship with borrowers. In the training guide (the "textbook" for CMs to learn the details of this work), there are specific requirements for CMs (shown in figure 1). Primarily, these standards emphasize a friendly relationship, while maintaining professionalness, fairness, openness, and honesty.

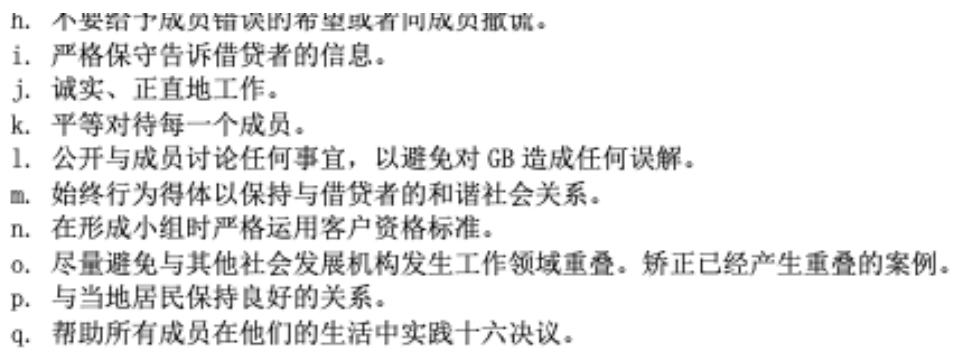

Figure 1. Practice Guideline for Better Life Microfinance

Translation of the texts in figure 1:

i. Strictly keep the information from borrowers confidential;

j. Work honestly and decently;

k. Treat every member equally and fairly; 
l. Discuss anything with borrowers in public, openly, in order to avoid any

misunderstanding about Better Life;

m. Always behave appropriately to maintain a harmonious relationship with borrowers;

p. Keep a good relationship with local residents

Mr. B, the top leader of Better Life, and an advocate of microfinance in China, hosted several training sessions for CMs. He has mentioned several times the kind of ideal relationship he sees for the borrowers and CMs. These ideal relations emphasize actions by MFI workers, such as "guiding", "evoking the potential," which is partially mimicking a teacher-student type relationship:

It is like teachers and students. They (the borrowers) see you (the CM) as a young college graduate with knowledge and experiences they don't have; they learn from you...

Our CMs are not loan officer; they are there to discover and evoke the potential and leadership from these women borrowers ... They have many names, such as Center Manager, Group Leader, Rural Revitalization Instructor or Women Entrepreneurial Instructor. But they are definitely not loan officers, or customer service managers because that would mean it's a debt relationship only. We are not like that.

— Mr. B, at a training session

In several training sessions, CMs share their understanding about the ideal relationship with clients. That it should be at an appropriate level is what most CMs take away. How to specify the "appropriate" level is up to everyone's own understanding, but it generally conveys an idea which I heard often in the training sessions from CMs: "We should be close to clients, because we need to meet them every week, and know how their businesses are going, and any difficulty they have; we should also not be too close, because we don't want our clients come to 
us and ask us to loosen some requirements for them just because we are close enough. We need to avoid that by maintaining an appropriate level if closeness in the relationship." (said by a Center Manager at Better Life at a training session)

All the above are the expected level and kind of relations the designers and leaders of the Better Life MFI hope CMs could maintain. These are standardized in the guide book, explained in Mr. B's speeches, and internalized in the CMs' own understanding. These relations mimic various different types of relationships in daily life, such as a patron-client relationship that emphasizes professionalism, a teacher-student relationship that emphasizes guiding, and a family-friend relationship that emphasizes intimacy. But all with a certain level of distance. These imagined relations, on what to do and what not to do, and how to do it, and at what level, reveal a kind of institutional goal of doing microfinance work. In the MFI's view, these relations should remain objective, fair and transparent, which is the main criteria for being professional. And it also comes with an appropriate level of both intimacy and distance that is rooted from the working principles of sincere respect and empathy.

However, what is neglected at this institutional goal of imagined relations is that relations take time and effort to forge. It is also a constantly evolving process of relational dynamics as time is spent in accumulated work routines. The effort should not be taken-for-granted either. These efforts would only come into practice when workers hold similar matching ideas about their relationships with microfinance workers, with the same imagined criteria mentioned above. In practice, there are many more concrete examples of the worker-borrower relationships occurring in the work routines that are often beyond the kind described previously. 


\section{Relational Work Theory}

Relational work is a theoretical tool brought to the analysis finance by Zelizer to challenge that notions of the separate spheres between "the economic" and "the intimate", or "the social". The paradigm of relational work is an extension the embeddedness paradigm of Granovetter (1985). In the embeddedness paradigm, actors are in a network of social structure and their positions in the network are influencing the economic actions they take, and are affecting the consequences of these actions (Wherry 2012: 204). However, the embeddedness concept largely "ignores how individuals negotiate, contest, and enact the roles they think they are playing." (Wherry 2012: 205) Instead, the relational work framework recognizes that the process of defining the nature of the relations is a kind of individual agency to connect with others, and socialize with others in their own way (Block 2012: 136).

Briefly, relational work is an approach that doesn't view the economic transactions and the intimate relations as separate spheres, hostile to each other; rather these spheres coexist, and there are certain matchings of economic transactions with intimate relations as interactions proceed (Zelizer 2012: 152). Specifically, when people negotiate the nature of their interactions, and their specific expectations of each other, they are doing relational work (Block 2012: 136). In other words, relational work is "the creative effort people make establishing, maintaining, negotiating, transforming, and terminating interpersonal relations.” (Zelizer 2012: 149)

The relational "packages" in the relational work analysis framework is the combination of four elements in any economic transaction: (a) distinctive interpersonal ties, (b) economic transactions, (c) media, and (d) negotiated meanings. Different elements and different combination of the elements create significantly different relational work (Zelizer 2012: 151). In the relational package, a central element is the process to make distinctive relationships. People 
make extra efforts of marking boundaries or distinguishing the relations by using certain media in a transaction, in order to deliver a certain meaning of this transaction that makes itself distinct from other ones (Zelizer 2012: 152).

Then what is the media in relational work? In the process of making distinctive relationships, media is often the tool the actors use to mark the boundary of the specific relationship in an economic transaction. As example Zelizer gives is about money transfer in the domestic household between parents and children. Rent money is one example of the media parents and children use to negotiate the current definition of their relations. Giving money to children, or charging children money — and in what way, and how often, and at what time —are all specific examples of markers in relational work. Oftentimes, the media in relational work is money in economic transactions. However, media could also be other "virtual" currencies people creatively create and use to manage their relations. For example, the media can also be time, favors, a compliment made in public, or a stroking of an ego. There are many kinds and many flavors. All of these media are tools for people to use in practicing the right kind of relations they perceive. In the social relations in microfinance, the media is also diverse. Even though the primary media is credit and debt (which flows between debtor and creditor), there are many other forms of media people use in everyday interaction, such as a favor to pay for bus fare, or a small gift that is reciprocal for the favor...

As Zelizer notes, "The concept of relational work invoked in economic activity ... provides tools for analyzing the constitution of economic transactions.” (Zelizer 2012: 144-145) This concept of relational work is key for understanding that economic transactions are not only about economic exchanges, but also about meaning-making in the various interactions. People put efforts into daily interactions to mark boundaries of the distinctive relations they have with 
others. The distinctiveness matters so much because different types of relations have different consequential effects, which come from different cultural and social expectations in different relations.

The concrete meanings articulated by the MFI workers reveal how these workers view their job, view microfinance, and view their clients (the borrowers). Inevitably, through the daily work routines of interactions, actors in microfinance situations are also forming social relationships other than just debt-credit relationships (that seem to only describe commercial relations).

With this in mind, before evaluating whether microfinance works or not, the central question becomes how do different relationships shape microfinance, and conversely, how does microfinance, with different borrower-lender relations, shape the practice and experiences of this particular type of financialization onto people's lives?

\section{Relational Work in Microfinance}

\section{Invoking Borrowers' Empathy}

Relational work lies in the context of microfinance ground work. Kar has shown an example of how workers invoke empathy from women borrowers when workers are trying to collect repayment. The workers tell a woman who has been in default, in a sentimental tone, that not collecting repayment would affect the worker's salary and promotion. In these affective persuasions, microfinance workers are asking the woman to think about the worker's uncomfortable position they are put in by the borrower, by her not repaying. The woman finally made some repayment in this interaction, which may not have occurred if she has not been told the situation of the worker (Kar 2013: 488). A relational lens would be useful in analyzing this interaction. A Relational framework would emphasize the "poor employee" role the workers 
play in this interaction of collecting repayment and how borrowers should react to this role the worker is playing. This process of identifying the roles of MFI workers (debt-collector and poor employee) and women borrowers (debt-payer and empathetic woman, or nice neighbor) helps us understand the nature of this economic transaction: it's more than collecting repayment and paying a debt; it is also filled with spontaneous and continuous relational work that defines and redefines their relationships.

\section{Expecting Reciprocity of Respect and Recognition}

Zeli had worked at Better Life for more than three years. She often likes to recall stories and moments in the previous site of Better Life, where she experienced the rural practice of microfinance. She shared two emotional moments about how the members treated the workers, including herself. (Essentially most of the borrowers are members, because every borrower has to be a member first; but not all members eventually get loans). "Oh, one time the rural villagers came to us and gave us baskets of walnuts, the ones they have planted themselves. They don't even give it to the officials in the village, who may have actually helped them more, so we felt that was very special." When Zeli was sharing this story, I can see the happiness on her face which was almost a sense of pride. The walnut gifts from the villagers (members) carry meaning of a further relationship, and the expression from Zeli when describing the story shows the significance this has to her and other workers.

But there was also one occasion in which Zeli was put on spot by a member's husband.

The following is a story she shared with us after dinner in the dorm. It was during a center meeting that Zeli, the center manager there, had hope that borrowers from the lower side of the village could travel to a middle point to join the meeting with other villagers from the other side. The important reason for her to insist on this location is that it would bring people together at one 
place at this center meeting. However, this borrower's husband was against this, and just slapped the money on the desk, angrily commenting, 'Isn't it just a loan?! (不就是个贷款吗？！ bu jiu shi ge dai kuan ma?!)" She was trying to persuade the member's husband but failed. This irritated reaction from the member's husband even made her cry in front of all the members, because she felt that "I thought we've met for so many times over the past few months and we had more than just a lender-borrower relationship.” For Zeli, being viewed in this way, demonstrated a lack of respect to her and her work. She thought the relationship more. And it should have had some level of mutual understanding which would come out of past familiarity and friendliness.

These two contrasting stories told by Zeli show one kind of expectation from CMs regarding their relationship with the borrowers at Better Life. This expectation is consistent with the desired qualities for workers at the MFI. "This is a job dealing with people; we need to put in emotion and sentiment.”. Here, the personal characters of Zeli and her working-style illustrated the intimate nature of the worker-borrower relationship, or lender-borrower relationship, when we think of workers as the frontline people representing the debt relationship. It was exactly this kind of interact that Graeber describes about debt: Debt is just one part of "human economies": economies "... in which what is considered really important about human beings is the fact that they are each a unique nexus of relations with others" (2011: 208). In Zeli's working routine at Better Life, the purpose and outcome of working with the borrowers is definitely beyond just making loans. It's more than debt relationship. There is some kind of "reciprocity" expected, not in the way of material rewards or gifts, but in the meaning of being appreciated, being respected. As shown in previous example about relational themes, stories between workers and borrowers are of all kinds, and all go beyond the pure debt relations. In the walnut gift example, 
walnuts are the media that is used by the villagers (mostly borrowers) to show gratitude to the workers. What is special about this gift is that it is not given to the officials in the village, who have actually done more help to the villagers. The significance or meaning behind this walnut gift is to show that the villagers see the workers as people they like, and want to show gratitude toward. The media of the walnut gift not only brings borrowers and workers closer, but also recognizes the work done by the workers in the microfinance program at the rural site. This recognition become what Zeli feels proud to share about; work accomplishment in the last program.

A better example of showing distinctive relations formed between borrowers and workers is perhaps the reaction of Zeli's crying when she was challenged by a member's husband. She specifically mentions that her perception of their relationship should not be just about loan; it's also friendship-like, which is more understanding and supportive. In this example, the media is the disagreement of a meeting location, or more precisely, the words from the borrower's husband. Being viewed as a money-lender only, Zeli doesn't feel respected, and even feels disappointed that she is nothing more than a person who gives out loans. For Zeli, the relationship between herself and the borrowers/borrowers' family is one of friendship —one that is much more stable than a shallow debt relationship. The working style of Zeli is consistent with such understandings about worker-borrower relationship. She once told me that there must be some emotion and feelings put in this work. For her, this work means interacting with people and therefore putting in effort to make a close relationship; and hopefully, then getting positive feedback or some similarly close response from people she has worked with. 


\section{More Sincere, Less Superficial}

One CM shared her understanding about a relationship with a member: "There is one occasion when we, together with the officer from the CEB, passed by a store selling gold accessories. The officer from the CEB was addressed as 'Hi, beautiful!' by the owner of the gold store, yet our members would never call us 'beautiful', they called us 'Nini', 'Little Ma.' Our members see us as appreciating what we do, and show gratitude many times for our efforts—not an attitude like 'I'm a client so I'm the God.' We are all loan officers (we CMs and the officer from CEB), but we have different feelings." These nicknames members use for CMs are typical Chinese naming patterns, where seniors call juniors in certain prescribed ways. ("Senior" and "junior" are different levels in the social hierarchy, the levels being determined by such things as age or gender). In Nini's view, this nickname is less superficial and portrays a more amicable and sincere relationship.

On the contrary, when it comes to how CMs address borrowers, they in practice behave differently from what the leader of Better Life envisions. The leader of Better Life, Mr. B, said in a training session that "We should call our members as Ms. X, not Sister X, or Auntie X. That's not professional." However, it is very common for CMs to call the borrowers Sister X, or Auntie $\mathrm{X}$, naturally, out of cultural habit and in, essentially, respect for the borrowers. Being professional and being respectful do not necessarily go against each other, but it is an interesting example that shows the gap between standard professionalness expected by the management and cultural habits practiced by the MFI workers on the ground to not always overlap.

From these examples of relational work, it becomes clear that MFI workers do carry specific social expectations and understandings in their relations with the borrowers. In general, they create a distinctive relationship that is beyond the borrower-lender relationship, and also 
expect reciprocity of respect and trust. The kind of microfinance they accomplish naturally

comes about with care, respect, sensitiveness and patience, which are all deeply apparent at the BL field site.

\section{What Kind of Financial Product is This?}

Whether microfinance is helpful for borrowers is a hotly debated question. From perspective of MFI workers, this is also a question they are struggling to answer. To answer this question, there are three features of the microfinance product to look at: interest rates, repayment method, and group meetings. These three features are often the must-mention points in the CM's everyday sales pitch. How they describe each feature to borrowers and how they internally discuss these features show an interesting contrast. This contrast helps reveal the "betwixt and between" position MFI occupy workers as they try to reconcile their responsibility to the MFI as an employee to sell the products, with their views of various features of the financial product.

\section{Defending the Distinctive Advantages of this Product: Weekly Repayment}

In a training session, a branch manager mentions that there are all kinds of alternative loans in the market for some poor people:

The 'CEB 5321' loan, also the RCB's interest-free loans are available and targeted at poor people (RCB is Rural Commercial Bank). The government has tried ways to make financing available for the poor. However, they are not designed well for the poor. They are one-time payments which puts huge pressure on due dates. That's why our product is a better fit for people: it is a weekly repayment, so it is a small payment each time, with much less pressure.

In everyday recruiting activities, CMs also make weekly payment a special feature that needs to be pointed out for promotion. It often become a rhetorical question from the potential borrowers when CMs mention that this loan will be repaid weekly: "Why is there a weekly repayment? That's so much trouble. Why not just a one-time payment or monthly payment? Like 
what most banks do." CMs are used to these questions, and they never find this question hard to answer. CMs naturally and smoothly say without much hesitation: "For a small business as yours, there must be some daily cash flow. Therefore, weekly payment is actually better because you just need to take out some portion from the daily cash flows regularly. If it's one-time payment, you might have bigger pressure of repaying all at once on the due date."

Here, I won't go further into the technical advantage and disadvantage of whether weekly installments are better than a one-time repayment, although it is a more common to repay monthly. But oftentimes, the weekly installment method is felt to be too troublesome for some clients.

Putting the discussion of repayment schedule aside, the main purpose of presenting this example is to show that the MFI workers have a consistent, well-formed narrative about the weekly installment of microfinance repayment. What's more interesting is that the MFI workers internalize and justify the advantage of weekly installments. It was exactly these justifications that makes the worker feel they are defending the poor. They would justify things by saying this is a better option for the poor, who may be easily getting into the trap of financial destitution or fraud otherwise. The workers are showing care and protection for the poor by arguing that the weekly installment is the best way of repaying for the poor.

\section{Interest Rate Confusion}

On the official promotion brochure of the Better Life microfinance program, the interest payment is illustrated in a calculation table [Figure 2]. It uses $¥ 10000$ as an example of the principle amount; with the weekly interest payment of $¥ 7$, the weekly principle repayment is $¥ 200$, in total the weekly repayment amount from the borrower should be $¥ 207$. The total interest payment for $¥ 10000$ is $¥ 316$, to be repaid in 50 weeks. 
1、金融扶助:

提供小额低息创业资金 (无抵押、无担保)

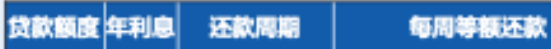

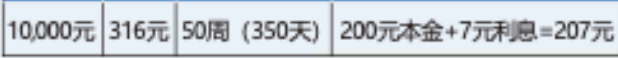

Figure 2. Interest Table from the Better Life Brochure

The total of interest payment would be added up to 316 before the 50 weeks installments. In fact, CMs often explain this to potential borrowers beforehand specifically so that they don't have to pay interest on last month because the accumulation of interest payment $¥ 7$ has grown to be just right for the total interest payment before the last month installment. They sometimes do the calculation on site with the borrower to illustrate the 50 weeks repayment schedule.

In the daily work of recruiting new members, there are different reactions to the same product when it is presented in different ways, especially when describing the interest rate. When the CM mentions that the interest payment for $¥ 10000$ is $¥ 316$ for one year, people mostly find it a good deal, and sometimes even ask further about the application procedures. However, when $\mathrm{CM}$ mentions the number $5.77 \%$, which is the annualized interest rate, some people find it acceptable, but quite significantly some people would feel that $5.77 \%$ sounds more expensive than $¥ 316$. When I shared this observation with one CM, Shasha, she explained further about her understanding of the interest rate: "Actually, our loan is repaid weekly which will lead to a higher annual interest rate than $5.77 \%$. This number $(5.77 \%)$ is calculated by the CEB on a monthly basis because they take the repayment each month (even though we ask the members to repay each week).”

It has been a debate among the CMs about what exactly is the interest rate and how does everyone understand it. They also think about how borrowers view this rate: 
It's overall a relatively low interest rate, but a little bit higher than a commercial bank.

It's not a bad interest rate at all.

The interest rate is not really that low because our repayment is weekly; considering the time value, this annual rate should be higher than the $5.77 \%$ we claim. But this is calculated based on the CEB's loan recovery schedule, which is by month, so the $¥ 316$ interest payment would make it about $5.77 \%$ as the annualized interest rate.

We can't explain very well in detail to potential member about this interest rate; it only makes people more confused about the interest rate.

People would feel 316 is a low interest payment, but sometimes when they hear $5.77 \%$, it sounds like a high interest rate.

Here, CMs argue about the nature, and the characteristics of the interest rate of this product they are promoting every day. Most of them talk about the interest rate as one feature to be highlighted in the sales pitch, while some others say it is not actually not much of a cheap alternative. There is no definition or standard of "cheap" and "expensive." Yet, it was exactly these debates on the cheapness and expensiveness, and the fairness and unfairness, about the interest rate that reveals the inner logic of the CMs. There is an unspoken tension over how they feel about the interest rate, which is tentative and uncertain in their own debates compared to how they talk about it to potential borrowers (where it is presented as certain and affirmed).

\section{Group Formation}

Group formation has long been the theoretical lynchpin of microfinance by creating social capital, and even social solidarity, among women. In various trainings sessions I have attended at Better Life, social capital was emphasized whenever group formation is mentioned. For microfinance program operations, social capital creation through group formation and weekly meeting is a core part of the theory and design and practice the program. Scholarship on microfinance with social capital has all kinds of arguments on whether this works or not. 
However, when MFI workers go out and try to recruit women borrowers, they don't mention this feature first, and sometimes they may leave it to the very end to explain it.

One reason for delaying the explanation of this feature is that CMs have a general perception on why women borrowers would apply for this loan. It is not primarily because of its social purposes or development goals, but often because this microfinance product is felt to be just a cheap alternative of other loan products available to the women borrowers. Therefore, the key of sales pitch doesn't need to emphasize the group meetings, but instead weighs heavily on financial features such as "no collateral, no guarantor needed;" low interest rate, the loan amount, and so on. Another important reason is the stigma related to group lending. Most women borrowers are sensitive to this group formation and worry about being obligated to pay for others who default. CMs would immediately jump in to explain when they sensed the hesitation: "No worries! There is no obligation among you and your group members."

\section{Conclusion}

All these three features discussed here about microfinance are the hotspots of discussion by microfinance workers in their everyday work routine. The biggest puzzle to solve in these discussions is whether this financial product is actually helpful for the poor women or not. Why or why not? Sometimes MFI workers give a clear, certain answer about certain features, but

hesitate on other features such as interest rate. The confident opinions are also strongly related to the training, in which the core concepts and core principles of this microfinance product is justified. However, the perception of these financial features, or the expectation and understanding of worker-borrower relations, cannot be simply justified by the training from the MFI. The common knowledge from local experience, and social expectations from the cultural context, shape the attitude of the MFI workers on microfinance. MFI workers have their own 
understanding of what this financial product is, who it serves (or should serve) or not, and whether or not it is helping. These inner reflections serve in stark contrast with the promotional sales pitch. 


\section{CHAPTER V: CONCLUSION}

Debt has long been considered a burden, an additional obligation people would like to get rid of as soon as possible. In the Western tradition at least, debt is commonly associated with the loss of power (Elyachar 2012). However, microfinance redefines the view of debt, and the commonly circulated discourse makes it closely associated with empowerment. When debt is associated with the loss of power, the debtor-creditor relationship is exploitative and oppressive. In other debtor-creditor relations like microfinance today, there are supposedly more reciprocal relations that are forged between the two key actors: borrowers and MFI workers.

In this thesis, I put the focus on microfinance on the key actors, MFI workers, and examined the internal understanding and confusions held by MFI practitioners. Throughout these chapters (especially Chapter 3 on aspects of workers' aspirations, and their tenuous positions; and Chapter 4 on aspects of worker-borrower relations), I have illustrated how microfinance works from the workers' perspective. This particular perspective has long been neglected in microfinance literature, where the focus has been mostly on the borrowers. Yet, this perspective from workers is essential for the understanding of microfinance (Kar 2013). Chapter 3 displayed the motivation, experiences and perception of their job from the workers point of view, which lead to the discussion of the workers' own interpretations of microfinance's mission and goals. Their interpretations don't necessarily go against the supposed mission and goal of microfinance as widely propagated in the media and by the World Bank, but it is certainly a compromised practice in reality, even with the efforts made by workers. Chapter 4 focused on the relations in microfinance between workers and borrowers, further showing what outcomes specific relational work brings to microfinance. In Chapter 4, I also presented some of the workers' own discussions on the features of what microfinance offers to women, which reveals workers' inner 
reflections about microfinance. With Chapter 3 and Chapter 4, as well as the background shown in Chapter 2 about the microfinance environment in China today, I have demonstrated a case for the usefulness of microfinance in contemporary China, from the workers' view. This thesis is about the motivations, positions and understanding of workers about microfinance, which shows that the efforts of making microfinance work has a lot to do with workers' own understanding about this job. Specifically, workers' understanding is a dynamic process that changes over time, as a consequence of their work experiences in the institutional environment. As a consequence, the developmental mission can drift away during MFI work due to specific barriers and contexts. Different relations influences on the process of financialization. It is essential to recognize this, and analyze the relations involved in any economic transaction for a better understanding about an economic activity like microfinance actually works.

\section{Understanding Motivation and Positions of MFI Workers}

In Chapter 3, I presented the kind of practices workers at this MFI do, the narratives they hold about working in microfinance, as well as their challenging in practicing microfinance. Through specific examples of how workers interpret this work at the ground level, it becomes clear that these on-the-ground practices and articulations are not separate from the kind of social, historical and institutional environment microfinance resides in. The expanded debt environment, in which the loan business is easily associated with financial fraud, has made both borrowers and MFI workers at a weakened position in this environment. In addition, the institutional constraints from the loan-funder (the CEB in this case) gradually become internalized and normalized by the microfinance workers in practice, making the them constantly trying to reconcile these constraints with their mission for creating improved development. Workers' aspiration, opinions, and practices related to the development mission are also dynamic processes that constantly 
change as the workers make negotiations each day on accomplishing social goals and accomplishing the KPI goal in this environment.

The contrasts shown in Chapter 3 about the aspirations, and the tenuous positions, of workers in MFI reveal that microfinance is not a magic experiment that could be replicated successfully anywhere by just following a model. There are many more about local contexts to consider before microfinance can work. By showing the inner contemplation and interpretation about why microfinance works or not, we can see microfinance practitioners, specifically the workers who carry out the mission statement in their everyday work, have very diverse understandings of this job. Their understanding about this job influence how $d o$ the job, how microfinance actually works, and how financialization happens in everyday life. Therefore, when looking at the practices and interpretations in relation to the social, historical and institutional environment of microfinance, it is essential to remember that the social goal of microfinance- as a form of financialization that incorporates the poor into a financial network, under the name (or purpose) of development—-should not be taken for granted.

\section{A Relational Analysis of Microfinance}

The management level at Better Life elaborated on the "ideal" relations they see in microfinance between workers and borrowers. These imagined relations are that more transparent, equal and professional relations, regulated by the microfinance guide book (the training manual at Better Life), are the ideal. Workers describe similar kind of relations but with more emphasis on a friendship and intimacy, though with some appropriate distance. However, the reality is a mixture of both of these. No matter what, the relations forge in all kinds of ways that go beyond mere debt-credit relations. The perception from workers about their relationship is a more amicable one, with respect and trust. 
In Chapter 4, I analyzed stories of interactions between borrowers and workers by recognizing how media, transactions, and meaningful relations, underpin these interactions. Three themes arouse as I analyzed relations in microfinance: 1) invoking borrowers' empathy as a communicative strategy; 2) expecting reciprocity of respect and recognition; 3) perceiving a more sincere relationship. There are definitely more dimensions about how to understand these relationships. Yet, these three key themes are revealing in their descriptions of the richness of social relations in microfinance. By making distinctive relations that are separate from other money-lenders, MFI workers at Better Life perceive and practice a more amicable kind of financial interaction. This led to patience, sensitivity, respect, and care in their everyday microfinance work.

As Zelizer points out, cultural, historical and institutional contexts do contribute to the interpretation of shared meanings, and the media people use to build boundaries of their distinct and specific relations (Zelizer 2012: 147, 164). However, the local practices of negotiating meanings happen all the time. Just as how MFI workers negotiate the meaning of their job with the claimed goal of helping the poor, they build "appropriate" yet constantly-evolving relationships with borrowers during their inevitable frequent interactions with them, albeit as a job requirement of accomplishing microfinance tasks. Indeed, this proves what Zelizer summarizes: "People do not simply adopt categories from the surrounding culture. Instead, they constantly negotiate and create new matches and adaptations, often transforming existing ideas and practices" (2012: 164). Understanding this dynamic process of relation-forming in microfinance helps us to see the gaps existing between the claimed relationships (such as teacher-student, mentor-mentee relations advocated by MFIs), and the actual-formed relations on 
the ground which is much more nuanced and rich in detail, and way beyond the mere lenderborrower relationship.

\section{Conclusion}

In Chapter 3, I have presented stories and narratives my microfinance workers at BL to show why they work in microfinance and what kind of actions they are limited to in practice. The challenges workers face here are due to a large social and economic environment (e.g., the workers received low position as money-lender and door-to-door salesperson), but there are also institutional constraints (such as the KPI pressure from the CEB and workers gradually adopting different screening processes that is held by traditional banks such as the CEB).

No matter what motivation and aspirations workers have when entering this job, be it with the dream for changing the world or not, their interpretation of "doing the job or helping the poor" evolves as they face the challenges at daily work. As a consequence, "help" is interpreted as "fulfilling capital need" most of the time, and the pressure of finding enough clients further pushes workers to reinterpret the definition of their clients to finish the targeted amount of loan issued. This is the compromised development: "Enough good clients" vs. "ideal clients".

Even though there are constant efforts in weekly meetings to accomplish the social development component intended in MF, their efforts are less visible than the loan itself, which leads to my conclusion in chapter 4: The financial features in microfinance are emphasized the most in workers' opinions about what kind of financial product microfinance is. This leads to borrowers perceiving microfinance mainly as a kind of loan, at most — and a loan with some other constraints, such as having weekly meetings. However, workers still expect a more reciprocal relation in which respect and recognition is desired in the relationships between workers and borrowers. They try to foster these more intimate relationships (compared to a pure 
borrower-lender relationship) with having respect, sensitivity, patience and empathy towards women in this work. By using a relational work framework in understanding the meaningfulness of these relations, it is clear that the efforts made by workers to accomplish the social goals have shaped the relations to be more than an economic transaction. Microfinance is equipped with mutual expectations of social reciprocity from both workers and borrowers, which is a concrete example how relational work shapes financialization.

One tension in this thesis is the conflict of two ideas. On one hand, understanding microfinance workers' relations with borrowers points to the importance of integrating microfinance work into local culture, by recruiting local staff who come from the same area, with a deep understanding of how to work better with the borrowers, and definitely with the social work component that emphasize empathy, respect, care and sensitivity. These arguments hold true under the premise of recognizing the potential of microfinance in poverty alleviation and women's empowerment. However, the other side of the conflict in this thesis lies in the tension between debt and development within microfinance itself. The social effects of microfinance have been debated for decades and indeed, the it is hard to make a definitive conclusion about its usefulness. What I have found in this research is that microfinance is primarily viewed as a tool for fulfilling capital need, and while it can be interpreted as the first step for further social development or empowerment, it is hard to justify why microfinance itself—i.e., the loan itself-reduces poverty.

David Mosse argued that a development institution "primarily functions to mobilize and maintain political support...rather than to orientate practice." (Mosse 2005) What microfinance misses in its practices is to bring (or lead) fundamental structural changes to poverty situations. Even when income is raised because of a good investment in their business, microfinance can't 
prevent vulnerable borrowers from facing other risks in life. Even when the social capital formation brings strong solidarity among women borrowers, the rooted inequality in the urbanrural resources — and lack of opportunities, or an adequate welfare system — are all barriers which are hard to conquer in bring development to poverty-stricken areas.

Last, I would like to give a bit more discussion on the question: Does MF indeed alleviating poverty or empowering the women in China? I'm quite uncertain about this question. Definitely I can't say yes confidently because I found the current "help" MFI gives to women is mainly out of the motivation for fulfilling capital need. If a women borrower's business seems to be making more profit or is growing - which is often the story told in the promotion material of microfinance - it seems like a successful story, telling of how microfinance makes women and their families get lifted out of poverty. However, the loan itself cannot be the sole or primary explanation for women's income increase or better livelihood. The more fundamental question to ask when evaluating the performance of microfinance should not be centered on business success or expansion, but also incorporate social aspects, such as whether there has been an increase in personal confidence, improved family health, money of children's education, as well as many other dimensions that determine improved resources or opportunities. What's more, many of the borrowers already have access to credit, but this microfinance program is perceived as a cheaper loan for them-which often remains an empirical issue. The current function microfinance plays is mainly about fulfilling capital need at a cheaper cost (and the cost varies at different MFIs).

Nonetheless, I would acknowledge that microfinance is working in some cases and some aspects. First, the MFI I studied was creating social capital for the women borrowers at times. The dynamics at each group is different but some groups develop a positive supportive atmosphere in the group meetings. In this process of creating positive social capital, MFI 
workers have often put in great effort into making groups with a positive atmosphere, (despite the dynamics of a group, or many other elements out of their control). For example, the social capital and dynamics of a microfinance group has a very diverse range, and requires more detailed analysis (e.g., Radhakrishnan 2018). Second, the microfinance organization I studied indeed lent to some women who would have no other ways of borrowing, which is a manifestation of their mission of targeting the "unbanked." This particular capital need was indeed a gap that got filled by microfinance and financial inclusion. But this small group of unbanked women are very few in the expanded credit environment in China today. Whether lending is actually good for poor women, and if so, at what interest rate, and in what way should this loan work, are all up to more discussion.

Therefore, I find it very hard to answer whether this microfinance project is successful. What is certain is that microfinance is not the magic bullet which can accomplish poverty alleviation immediately, or empower women effectively. But I can't deny the efforts the MFI workers made in trying to help the women who need some additional capital (fulfilling the need of borrowing), or giving women more support by expanding their social circle (when considering that is a positive thing). And the prepared discussions on financial or personal topics at each meeting - such as teaching women how to recognize fake currency, how to communicate with their children, how to weather through the business difficulties - were also no doubt greatly beneficial. Last, the mental and moral support given to the women by MFI workers when the women borrowers' businesses or families faced difficulties were also important things to acknowledge. 


\section{Future Research}

More discussions need be had on various key stakeholders in the microfinance industry such as borrowers, workers, the microfinance advocates and the state. The first step of any development projects should be about understanding local livelihood strategies and concerns, workers' own social positions, and relations with local people. By understanding these issues before designing and implementing development projects, the key problems of poverty will more likely to be better exposed and understood. With such understanding in mind, any development experiments would be less likely to miss the chance to offer the more needed aid for the impoverished.

Specifically, for my future research agenda on microfinance, I hope to solve some questions I was not able to answer in this thesis. First, how do employees do the required relational work in their microfinance activities? What is it about the local culture that contribute to the relational work efforts? Is there anything else going to encourage or discourage their relational work efforts? Second, how do we reconcile relational work of the MFI workers with the unequal power dynamics inherent in microfinance? The power dynamics changes depending on different contexts when workers and borrowers are situated in very specific situations. Sometimes the workers are more powerful since they obviously hold more information on the loan product and the application process. Yet, sometimes the women borrowers are more powerful as some of them hold keys to the local network which is essential for microfinance to enter in such situations, what would relational work look like and how we reconcile it with the unequal power dynamics? 


\section{REFERENCES}

Beck, Erin, and Smitha Radhakrishnan. 2017. "Tracing Microfinance Value Chains: Beyond the Impasse of Debt and Development." Sociology of Development 3 (2): 116-142.

Block, Fred. 2012. "Relational Work in Market Economies: Introduction." Politics \& Society 40 (2): $135-144$.

China Association of Microfinance. 2018. "Annual Report of China Association of Microfinance" China Association of Microfinance website, 2018. Accessed [July 8, 2020]. http://www.chinamfi.net/upload/link/1907/f046018.pdf

China Banking and Insurance Regulatory Commission, People's Bank of China. 2019. "China Inclusive Finance Development Report 2019" China Banking and Insurance Regulatory Commission website, September 29, 2019. Accessed [June 25, 2020] http://www.cbirc.gov.cn/cn/view/pages/ItemDetail.html?docId=847316\&itemId=915\&ge neraltype $=0$

Chu, Hongmei (褚红梅). 2014. "电商信贷与传统银行信贷的比较分析 (A Comparative Analysis of Credit Between E-commerce and Traditional Banks)."《市场论坛》Market Forum 6: 79-80, 91.

Collins, Daryl, Jonathan Morduch, Stuart Ruthford, Orlanda Ruthven. 2009. Portfolios of the Poor: How the World's PoorLive on \$2 a Day. Princeton, NJ: Princeton University Press.

Du, Xiaoshan (杜晓山). 2004. "中国农村小额信贷的实践尝试 (Microfinance Practices in Rural China)."《中国农村经济》Chinese Rural Economy 8: 12-19.

Elyachar, Julia. 2005. Markets of Dispossession: NGOs, Economic Development, and the State in Cairo. Durham. NC: Duke University Press. 
Elyachar, Julia. 2012. "The Passions of Credit and the Dangers of Debt" Society for Cultural Anthropology website, May 15, 2012. Accessed [October 1, 2019]. https://culanth.org/fieldsights/the-passions-of-credit-and-the-dangers-of-debt

Fungáčová, Zuzana and Laurent Weill. 2015. "Understanding Financial Inclusion in China" China Economic Review 34: 196-206.

Goodman, Racheal. 2016. “Borrowing Money, Exchanging Relationships: Making Microfinance Fit into Local Lives in Kumaon, India." World Development 93: 362-373.

Graeber, David. 2011. Debt:The First 5,000 Years. Brooklyn, NY: Melville House.

Grameen Bank. 2019. "Grameen Bank Introduction." Grameen Bank website, Last Updated December 2019. Accessed [July 5, 2020]. http://www.grameen.com/introduction/

Granovetter, Mark. 1985. "Economic Action and Social Structure: The Problem of Embeddedness." American Journal of Sociology 91 (3): 481-510.

Hsu, Becky Yang. 2017. Borrowing Together: Microfinance And Cultivating Social Ties. Cambridge: Cambridge University Press.

Kar, Sohini. 2013. "Recovering Debts: Microfinance Loan Officers and the Work of 'ProxyCreditors' in India." American Ethnologist 40: 480-493.

Kar, Sohini. 2017. "Relative Indemnity: Risk, Insurance, and Kinship in Indian Microfinance." Journal of the Royal Anthropological Institute 23 (2): 302-19. doi:10.1111/14679655.12608.

Kar, Sohini. 2018. Financializing Poverty: Labor and Risk in Indian Microfinance. Stanford: Stanford University Press.

Karim, Lamia. 2011. Microfinance and its Discontents: Women in Debt in Bangladesh. Minneapolis: University of Minnesota Press. 
Loubere, Nicholas. 2018. "Indebted to Development: Microcredit as (de)Marginalisation in Rural China.” Journal of Peasant Studies 45(3): 585-609.

Mosse, David. 2005. Cultivating Development: An Ethnography of Aid Policy and Practice. London: Pluto Press.

Nobel Media AB. 2006. "Grameen Bank - Facts." NobelPrize.org website, 2020. Accessed [July 5, 2020]. https://www.nobelprize.org/prizes/peace/2006/grameen/facts/

People's Daily. 2017. “Premier Li Keqiang Made Timeline: The Big Five National Banks Going to Set Up a Financial Inclusion Sector" 李克强总理定出时间表：五大国有商业银行全部设立普惠金融事业部" China News website, July 17, 2017. Accessed [June 1, 2020]. http://www.ln.chinanews.com.cn/news/2017/0717/62489.html

Portes, Alejandro. 1998. "Social Capital: Its Origins and Applications in Modern Sociology." Annual Review of Sociology 24:1-24.

Radhakrishnan, Smitha. 2015. “'Low Profile’ or Entrepreneurial? Gender, Class, and Cultural Adaptation in the Global Microfinance Industry.” World Development 74: 264-74.

Radhakrishnan, Smitha. 2018. "Of Loans and Livelihoods: Gendered 'Social Work' in Urban India." Economic Anthropology 5: 235-246.

Rankin, Katherine. 2001. “Governing Development: Neoliberalism, Microcredit, and Rational Economic Woman.” Economy and Society 30(1): 18-37.

Rankin, Katherine. 2002. "Social Capital, Microfinance, and the Politics of Development." Feminist Economics 8(1): 1-24.

Roy, Ananya. 2010. Poverty Capital: Microfinance and The Making of Development. New York: Routledge. 
Schuster, Caroline E. 2015. Social Collateral: Women and Microfinance in Paraguay's Smuggling Economy. Berkeley: University of California Press.

Stiglitz, Joseph E. 1990. "Peer Monitoring and Credit Markets." The World Bank Economic Review 3: 351-366.

State Council Leading Group Office of Poverty Alleviation and Development (CPAD). 2020.

"The Introduction of CPAD" The State Council Leading Group Office of Poverty Alleviation and Development (CPAD) website, 2020. Accessed [June 1, 2020]. http://www.cpad.gov.cn/col/col282/

Wang, Sangui (汪三贵). 2020. "中国扶贫绩效与精准扶贫 (The Poverty Alleviation Performance in China and Poverty Alleviation with Precision)." 《政治经济学评论》Political Economy Review 11(01): 130-148.

Wherry, Frederick. 2012. "Performance Circuits in the Marketplace." Politics \& Society 41 (2): 203-221.

Xinhua. 2020. "China Among High-performing Financial Inclusion Countries in Asia: Report" China Daily website, July 3, 2020. Accessed [July 8, 2020]. http://www.chinadaily.com.cn/a/202007/03/WS5efeac10a3108348172570dd.html Yin, Hang. 2018. “Current Status and Future Prospects of China's Peer-to- Peer Lending Regulation." Journal of Modern Economy 1: 6.

Young, Stephen. 2010. "Gender, Mobility and the Financialisation of Development." Geopolitics 15(3): 606-627.

Yunus, Muhammad.1976. "Microfinance and Poverty in Bangladesh." Journal Development Studies 37(4): 101-132. 
Yunus, Muhammad. 2003. Banker to the Poor: Micro-Lending and the Battle Against World Poverty. New York: PublicAffairs Books.

Zelizer, Viviana. 2012. "How I Became a Relational and Economic Sociologist and What Does That Mean?" Politics \& Society 40(2): 145-74. 